Portland State University

PDXScholar

1984

\title{
Inquiry into the causes and significance of cytoplasmic vacuolation of neutrophils in the peripheral circulation
}

Gary Xavier Haight

Portland State University

Follow this and additional works at: https://pdxscholar.library.pdx.edu/open_access_etds

Part of the Biology Commons, and the Cell Biology Commons Let us know how access to this document benefits you.

Recommended Citation

Haight, Gary Xavier, "Inquiry into the causes and significance of cytoplasmic vacuolation of neutrophils in the peripheral circulation" (1984). Dissertations and Theses. Paper 3400.

https://doi.org/10.15760/etd.5283

This Thesis is brought to you for free and open access. It has been accepted for inclusion in Dissertations and Theses by an authorized administrator of PDXScholar. Please contact us if we can make this document more accessible: pdxscholar@pdx.edu. 
AN ABSTRACT OF THE THESIS OF Gary Xavier Haight for the Master of Seierice in Biology presented May 4, 1984.

Title: Inquiry into the Causes and Signiticance of Cytoplasmic Vacuolation of Neutrophils in the Peripheral Circulation.

APPROVED BY MEMBERS OF THE THESIS COMMITTEE:
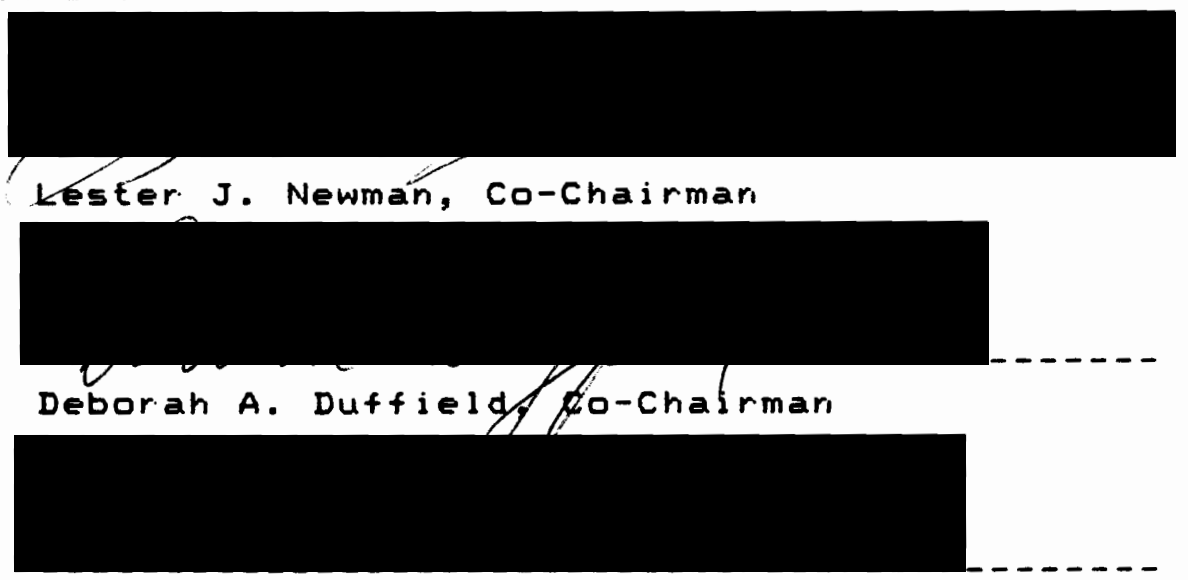

Malcolm S. Lea

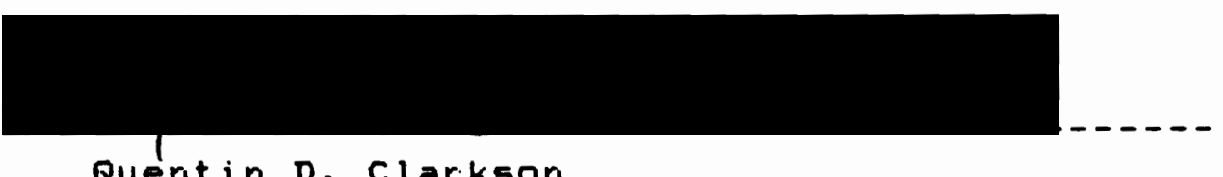

Queritin D. Clarkson

One-half million cases of septicemia are reported arinually with a mortality of arourd $35 \%$. Diagnosis depends in part on blood cultures which require one to two weeks. It would be advantageous if an early sign of septicemia were available.

Cytoplasmic vacuolation of polymorphonuclear neutrophils is occasionally seer in the peripheral blood smears of 
patients who have infections. The object of this work was to determine the cause and significance of cytoplasmic vacuolation with the goal of using the occurrence of vacuolation as an early indicator of infection.

It was necessary first to establish that the pheriomenon was not simply an artifact of slide preparation techrique. Having established that, I examined the records of 59 patients displaying vacuolation. The major finding was that presence of vacuolation is weakly correlated with a number of variables. Sixty-three variables were examined for each of 59 patients using multiple regression analysis. Fifteen variables made a significant contribution to the regression equation and accounted for $62 \%$ of the variability seen in percent vacuolation. Among the factors contributing were patient age, sex, presence of infection and history of alcohol abuse.

An animal mode! was developed using mice; a number of interesting but conflicting results were obtained. Although female in patients were represented in the vacuolation group twice as often as male inpatients, in mice the males were affected at an equal frequency but had twice as high a percent vacuolation. In addition I observed that the control animals ultimately demonstrated vacuolation to a degree equivalent to that of the experimental animals. Animals fed etriariol and animals who received bacterial injection developed vacuolation but those who got both the injection ard 
the ethanol had a lower incidence of vacuolation.

Finally in 트트므 induction of vacuolation was attempted using plasma from affected individuals and cells from healthy volunteers. Vacuolation appeared first in the experimental tubes (patient plasma and volunteer cells) but was everitually seen in the control tubes ivolunteer plasma and (e115).

The usefulness of cytoplasmic vacuolation as a diagnostic tool is limited by the fact that its presence is transient and is correlated with a number of factors besides infection. However, since $72 \%$ of the patients having vacuolated neutrophils are Ultimately diagnosed as having ar infection, vacuolation, when it is preserit, should serve as a warning of the possibility of infection. 
INQUIRY INTO THE CAUSES AND SIGNIFICANCE OF CYTOPLASMIC VACUOLATION OF NEUTROPHILS IN THE PERIPHERAL CIRCULATION

by

GARY XAVIER HAIGHT

A Thesis submitted in partial fulfillment of the requirements for the degree of

\author{
MASTER OF SCIENCE \\ in \\ BIOLOGY
}

Portland State University 
TO THE OFFICE OF GRADUATE STUDIES AND RESEARCH:

The members of the committee approve the thesis of Gary Xavier Haight presented May 4, 1984.

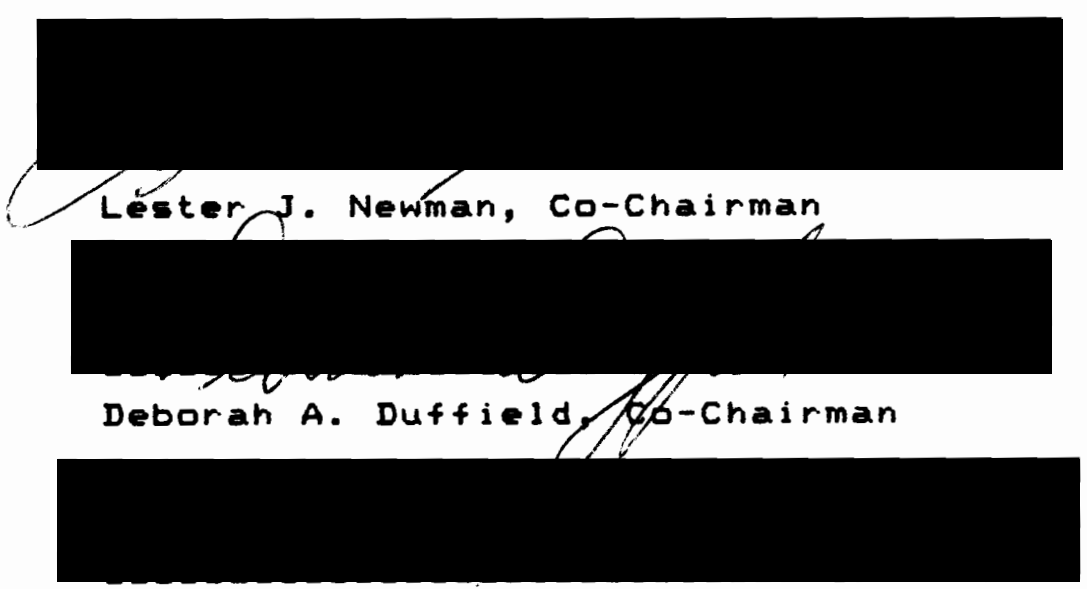

Malcolm S. Lea

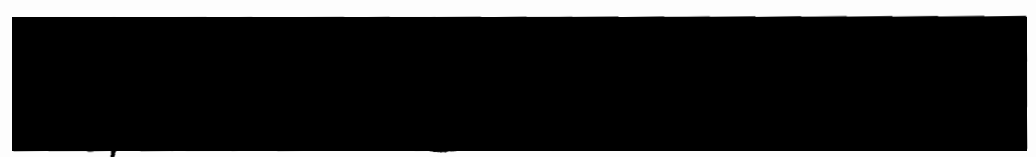

Quentin D. Clarkson

\section{APPROVED:}

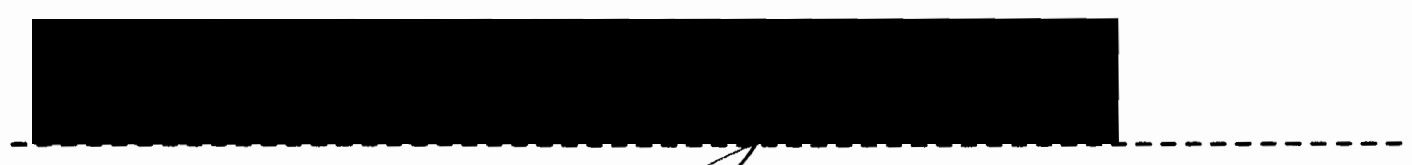

W. Herman Taylor, Head, Depertment of Biology

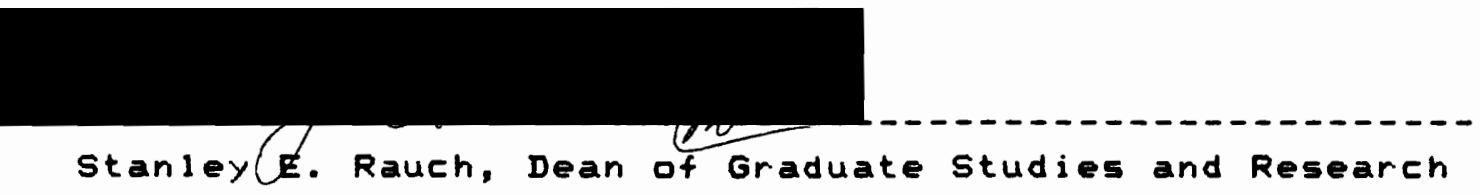




\section{ACKNOWLEDGEMENTS}

It is unlikely that without the enthusiastic teaching, encouragement and friendship of Dr. Debbie Duffield this Master's project would ever have begun.

The friendship and guidance of Dr. Lester Newman and Dr. Malcolm Lea and the statistical expertise of Dr. Deane Clarkson have been invaluable and much appreciated.

My thanks go to Caral Wilson who initiated me irito the mysteries of multiple regression and the Honeywell 66.

I am grateful to Paul Furatake for his professional production of the graphic figures which went into this thesis.

I wish to thank Karen Dodge, Carol Titsworth, and the hematology staffs of Emanuel arid Providence Hospitals for staining the hundreds of slides generated in this project and for their dedication in supplying me with blood smears from affected patients.

Very special thanks go to my wife, Rose, for her unwavering support and encouragement, and for never allowing me to give up when things appeared impossible. I couldn't have done it without you. 
TABLE OF CONTENTS

PAGE

ACKNOWLEDGEMENTS . . . . . . . . . . . . . . . . . .

LIST OF TABLES

LIST OF FIGURES

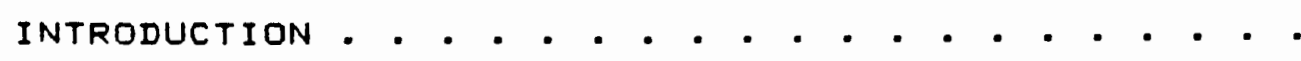

CHAPTER I EVALUATION OF ANTICOAGULANTS

INTRODUCTION • • • • • • • • • • • • • • • •

MATERIALS AND METHODS . . . . . . . . . . .

RESULTS

8

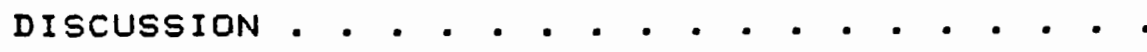

\section{CHAPTER II VACUOLATION IN PATIENTS}

INTRODUCTION • . . . . . . . . . . . . . .

MATERIALS AND METHODS

RESULTS . . . . . . . . . . . . . . . . . . .

DISCUSSION • . . . . . . . . . . . . . .

CHAPTER III VACUOLATION IN ANIMALS

INTRODUCTION . . . . . . . . . . . . . . .

MATERIALS AND METHODS - . . . . . . . . . .

RESULTS 
CHAPTER IU NITROBLUE TETRAZOLIUM REDUCTION INTRODUCTION . . . . . . . . . . . . . . . 39 MATERIALS AND METHODS . . . . . . . . . . . . . . 40 RESULTS . . . . . . . . . . . . . . . . . . 41 DISCUSSION $\ldots$

CHAPTER $V$ IN UIIRQ VACUOLATION

INTRODUCTION $\cdot$ • .

MATERIALS AND METHODS . . . . . . . . . . . .

RESULTS

DISCUSSION . • . . . . . . . . . . . . . . . .

FINAL DISCUSSION . . . . . . . . . . . . . . . . REFERENCES . . . . . . . . . . . . . . . . . . . 58 APPENDIX ......................... 62 


\section{LIST OF TABLES}

TABLE

PAGE

Occurrence of Vacuolation in Anticoagulated

Blood . . . . . . . . . . . . . . . .

Distribution by Diagnosis, Age, and Sex of

Inpatients Displaying Vacuolation....

II Sex Effect of Neutrophil Vacuolation in

Inpatients. . . . . . . . . . . . . . 20

IV Correlation Coefficients for Independent and

Combined Variables. . . . . . . . . . 22

$\checkmark$ Variables in the Regression Equation. . . . 23

UI Presence of Vacuolation arid Positive Nitroblue

Tetrazolium Tests in Four Groups of Mice

Run Number one .. . . . . . . . . . 42

VII Presence of Vacuolation and Positive Nitroblue

Tetrazolium Tests in Four Groups of Mice

Run Number Two . . . . . . . . . . . .

VIII

Percent Vacuolation of Neutrophils Exposed to

Patient Plasma Versus Time of Exposure. .

Ix Hourly Comparison of Meari Percent Vacuolation

of Experimentals Versus controls . . . 
1. Mature polymorphonuclear neutrophil. 2100x. .

2. Mature neutrophil showing cytoplasmic vacuolation. 2800x. . . . . . . . . . .

3. Neutrophil showing toxic granulation at 4 hours. EDTA used as anticoagulant. 2300x. . . .

4. Neutrophil showing slight vacuolation at 1 hour. Heparin used as anticoagulant. 1900x. . . 9

5. Frequency of occurrence versus percent vacuolatior for hospital inpatients. . . . . . . . .

6. Mature neutrophil with large vacuole. 2300x...

7. Mature neutrophils with many small cytoplasmic vacuoles. 2300x.............. 19

8. Normal mature neutrophil from a mouse. $2300 \times . .30$

9. Mean percent vacuolation for mice by sex and experimental group. . . . . . . . . . . . 31

10. Blood smear with distorted background. $2300 \times . .33$

11. Dccurrence of disrupted background by sex arid experimental group. . . . . . . . . . . .

12. Mouse neutrophil grossly distorted by cytoplasmic vacuoles. 2300x. . . . . . . . . . 38

13. Positive NBT test stimulated by phorbol 
$v i j i$

PAGE

14. Positive NBT test stimulated experimentally. . . 44

15. Percent vacuolation versus time for neutrophils in vitro. . . . . . . . . . . . . . 50 


\section{INTRODUCTION}

Phagocytic leukocytes are divided into two primary groups: the monocytic and the granulocytic series. The granulocytes are further divided into basophils, eosinophils, and neutrophils based on the staining characteristics of their cytoplasmic granules. In a normal peripheral blood smear the predominant leukocyte is the neutrophil. The most commonly seen neutrophil is the mature segmented form, easily identified by its multilobed nucleus and characteristic staining (Figure 1). The only other developmental stage normally seen in a peripheral blood smear is the form with an unsegmented or "band" nucleus.

Many morphologic changes in the neutrophil have been described in disease states 15tiene-Martin 1982a. StieneMartin 1982b). Sutro (1933) described the phenomenon of vacuolation of neutrophil cytoplasm as occasionally being seen in patients having bacterial infections. Meranze (1935) described neutrophils having a "motheaten" appearance from cases of both infectious and non-infectious disease. One investigator (Gordin 1952) attempted to correlate extent of vacuolation with severity of infection, while others (Ponder et al 1942) used cytoplasmic vacuolation of neutrophils as a measure of the severity of disease. Zieve et al (1966) found vacuolated cytoplasm in the neutrophils of $3 \%$ 


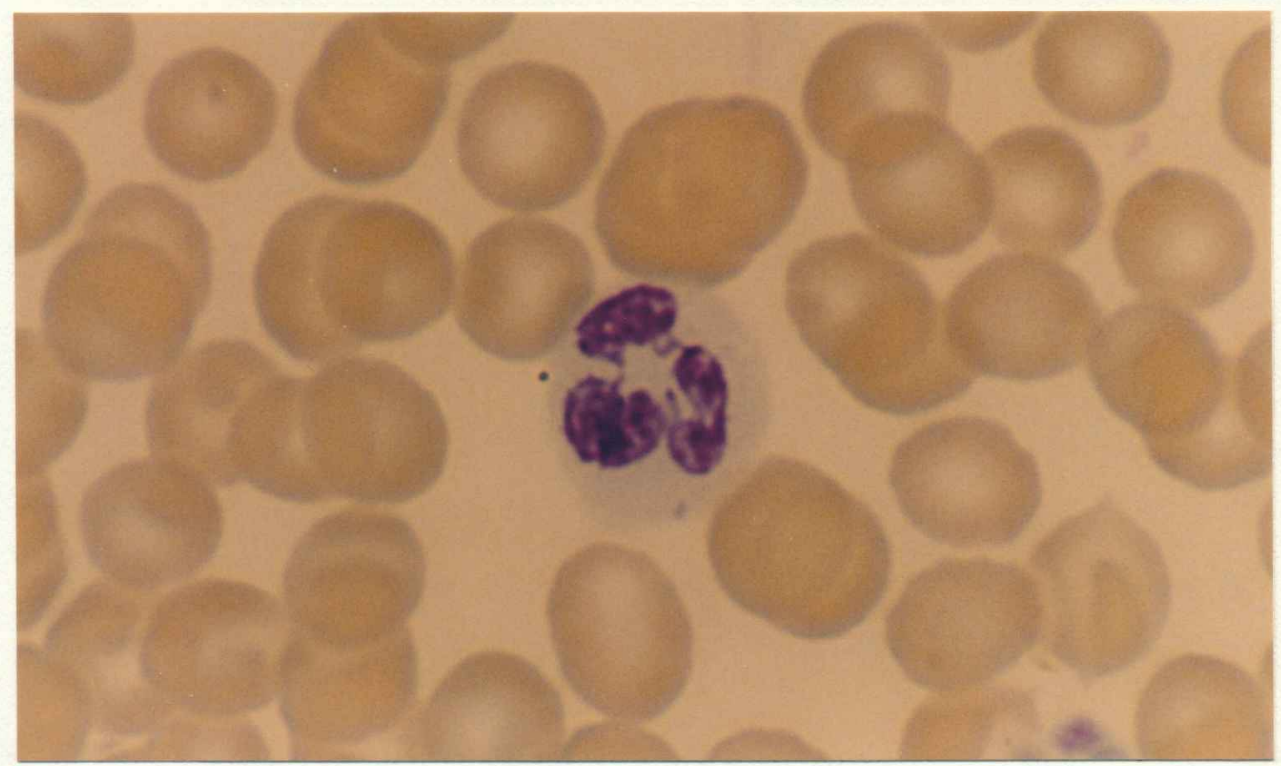

Eigure 1. Mature polymorphonuclear neutrophil. $2100 x$. 
of 3500 blood smears from a general hospital population. of this $3 \%$, 98\% were from patients whose primary diagnosis was bacterial infection. Cytoplasmic vacuolation has been observed in the neutrophils of persons treated for ethanol abuse (Lindenbaum and Lieber 1969; Davidson and McPhie 1980) and in the neutrophils of dogs being fed ethanol (Beard and Knott 1966$)$.

\section{Vacuolation of neutrophil cytoplasm was reported as} being transient, lasting only 12 to 24 hours 12 ieve et al 1966: Emerson 1970). The transient nature of cytoplasmic vacuolation in patients who respond to treatment corresponds well with the turnover rate of neutrophils in the peripheral circulation. The implication is that it is the circulating neutrophils which are affected, and that when stimulation ceases, they are rapidly cleared from the peripheral circulation. The half-life for neutrophils in the peripheral circulation has been variously reported (C1ine 1975; Greenwalt 1977; Wintrobe et al 1981) as 6 to 7.5 hours. The persistence of vacuolated cells was seen as a very negative prognostic sign (Wintrobe et al 1981; Grange 1980).

Spontaneous formation of cytoplasmic vacuoles in neutrophils in wet mounts was reported by Gordin (1952) and by Bessis (1972). Gordin (1952) noted that vacuole size increased at a constant rate, once formation had begun, leading him to the conclusion that vacuole formation was due to a physical process not related to cellular metabolism. 
He further concluded that since vacuoles form in wet films and are more often seen in older, more mature neutrophil forms, the origin of vacuoles is not a maturational disturbance, but is due to some peripheral insult. Mccall et al (1969, 1979) claimed that cytoplasmic vacuoles were autophagosomes caused by lysosomal membrane instability and that this instabilty was precipitated by exposure to bacterial chemotoxins. Bessis (1972) believed the vacuoles formed from a swelling of the mitochondria, rough endoplasmic reticulum and the golgi apparatus.

Solberg and Hellum (1972) examined neutrophils from bacterially infected patients and found that they were able to ingest but were less able to kill bacteria in vivo than were neutrophils taken from afebrile patients. Vacuolated neutrophils were present in $27 x$ of the infected patients and in only 8\% of the control patients. Cytoplasmic vacuolation is generaliy held to be a sign of degeneration and impending cell death (Bessis 1972, Wintrobe et al 1981). The phenomenon has been noted in senescent human fibroblasts (Finch and Hayflick 1977) and in the senescent hyphae of the mold

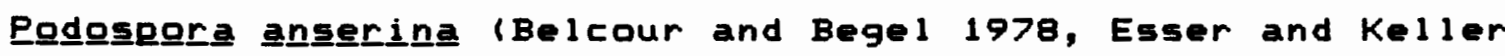
(976).

As many as one-half million cases of septicemia are reported annually with an overall mortality around $35 \%$ (Rubin 1981). Survival depends upon rapid diagnosis and treatment. A complication is that blood cultures require 
one to two weeks. It would be advantageous to have an early and reliable sign of septicemia.

I have noted from personal observations that cytoplasmic vacuolation of polymorphonuclear neutrophils is occasionally seen in the peripheral blood smears of patients having septicemia. Since an admission blood smear is examined for most hospital patients and since the vacuolation is readily apparent (Figure 2) I decided to examine more closely the relationship between infection and cytoplasmic vacuolation.

It was necessary first to assess the influence of the anticoagulants used in specimen collection on vacuole formation (Chapter I). Information was then gathered on patients displaying vacuolation to find the variables which best correlated with appearance of vacuoles (Chapter II). An animal model for cytoplasmic vacuolation was investigated (Chapter III), and an attempt was made, using the nitroblue tetrazolium reduction test, to determirie the applicability of the animal model (Chapter IV). Finally, Chapter $U$ deals with the ing 므트므 induction of vacuolation in neutrophils. 


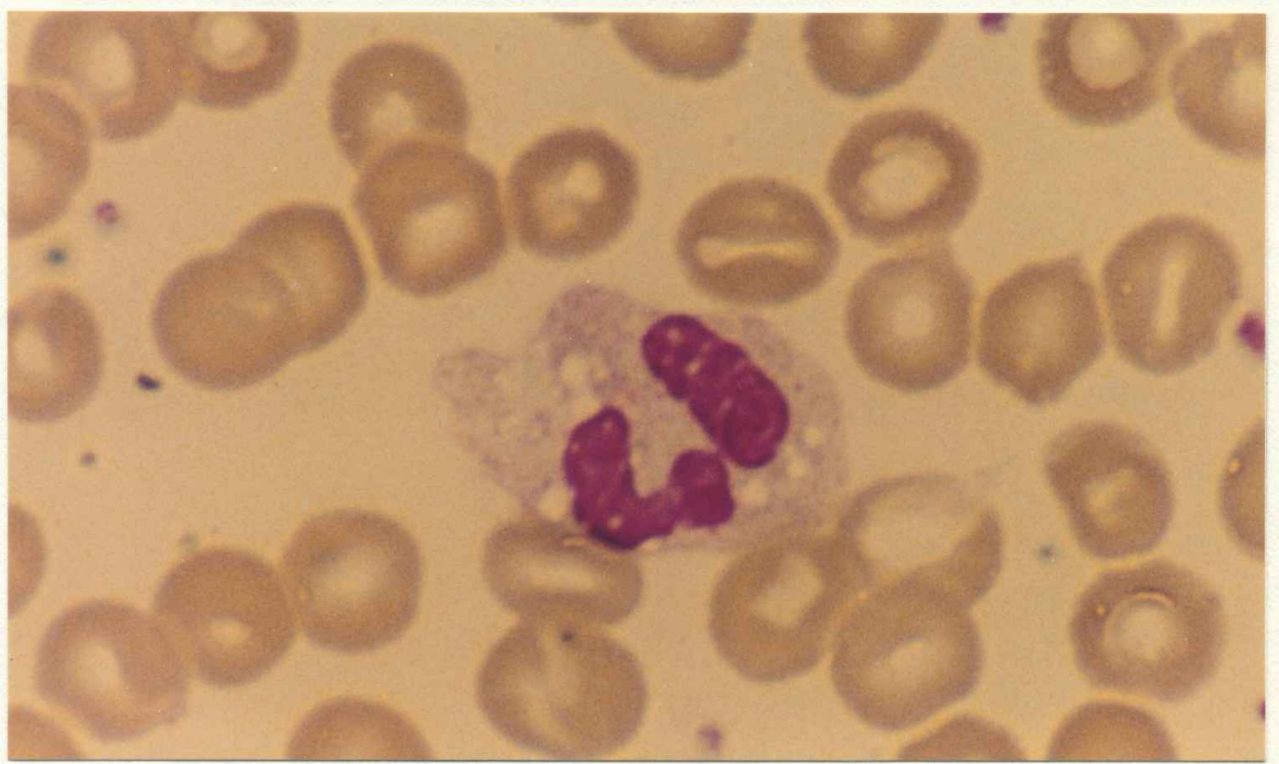

Eigure 2. Mature neutrophil showing cytoplasmic vacuolation. 2800x. 


\section{CHAPTER I}

\section{INTRODUCTION}

There is a common belief both among hematology lab technologists and in the literature (Davidson and Henry 1969; Shafer 1982) that exposure of blood to anticoagulants induces artifacts, including vacuolation, which render blood smears useless for diagnostic purposes. However, several hospitals in this metropolitan area make their diagnostic smears from anticoagulated blood, usually using EDTA, as anticoagulant.

Since, in some phases of my work it was easiest to obtain anticoagulated blood and since it seemed strange that technologists who warned of anticoagulant artifact induction were, in fact, using anticoagulated blood for their smears, this study was undertaken to ascertain the vacuole-inducing capability of various anticoagularits given prolonged in 느느으 exposure.

\section{MATERIALS AND METHODS}

Ten $10 \mathrm{ml}$ tubes of blood were drawn from a normal healthy subject. Pairs of tubes contained the following anticoagulants: sodium heparin, sodium oxalate, potassium oxalatel sodium fluoride, EDTA, and sodium citrate. As a control, needle-tip smears were made using no anticoagularit. 
One tube from each of the five pairs was held at room temperature $\left(24^{\circ} \mathrm{C}\right)$ and the other tube of each pair was held at 40c, the temperatures at which blood is commonly kept in a clinical laboratory. Blood smears from the anticoagulated blood were made at $0.5,1,2,3,4$, and 14 hours. The smears were air dried, fixed for one minute in absolute methanol, and stained with Wright's Stain on an Ames Hematek slide stainer. The examination of these and all subsequent smears was performed by bright-field microscopy at $1000 x$.

The smears were examined primarily for vacuole formation but color, cell morphology, and presence of other artifacts was noted.

\section{RESULTS}

Smears made from sodium citrate anticoagulated blood showed normal white cell morphology through 14 hours. Slight crenation of erythrocytes was seen at 14 hours both at $4 \circ \mathrm{C}$ and at $24^{\circ} \mathrm{C}$. The EDTA anticoagulated smears showed normal morphology through 4 hours. After 4 hours, toxic granulation, a coarse dark granulation of the cytoplasm commonly seen in toxic conditions, occurred in blood stored at $240 \mathrm{C}$ but not in blood stored at $40 \mathrm{C}$ (Figure 3 ). Again, red cell crenation was seen at 14 hours at both temperatures. Heparinized smears had $1 \%$ vacuolated neutrophils at 1, 3, and 14 hours at $4{ }^{\circ} \mathrm{C}$ and at 3 hours at $22^{\circ} \mathrm{C}$ (Figure 4 ). Potassium oxalatel sodium fluoride smears displayed 


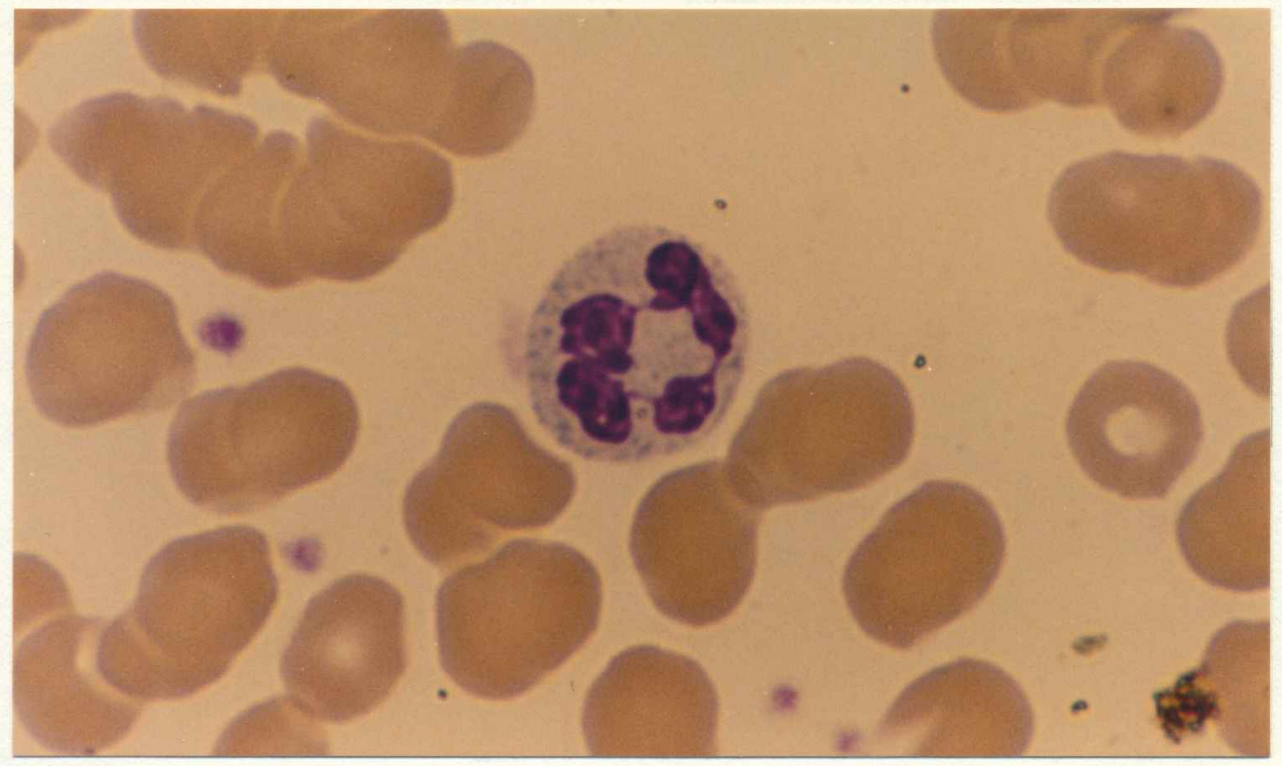

Eigure 3. Neutrophil showing toxic granulation at 4 hours. EDTA used as anticoagulant. $2300 x$.

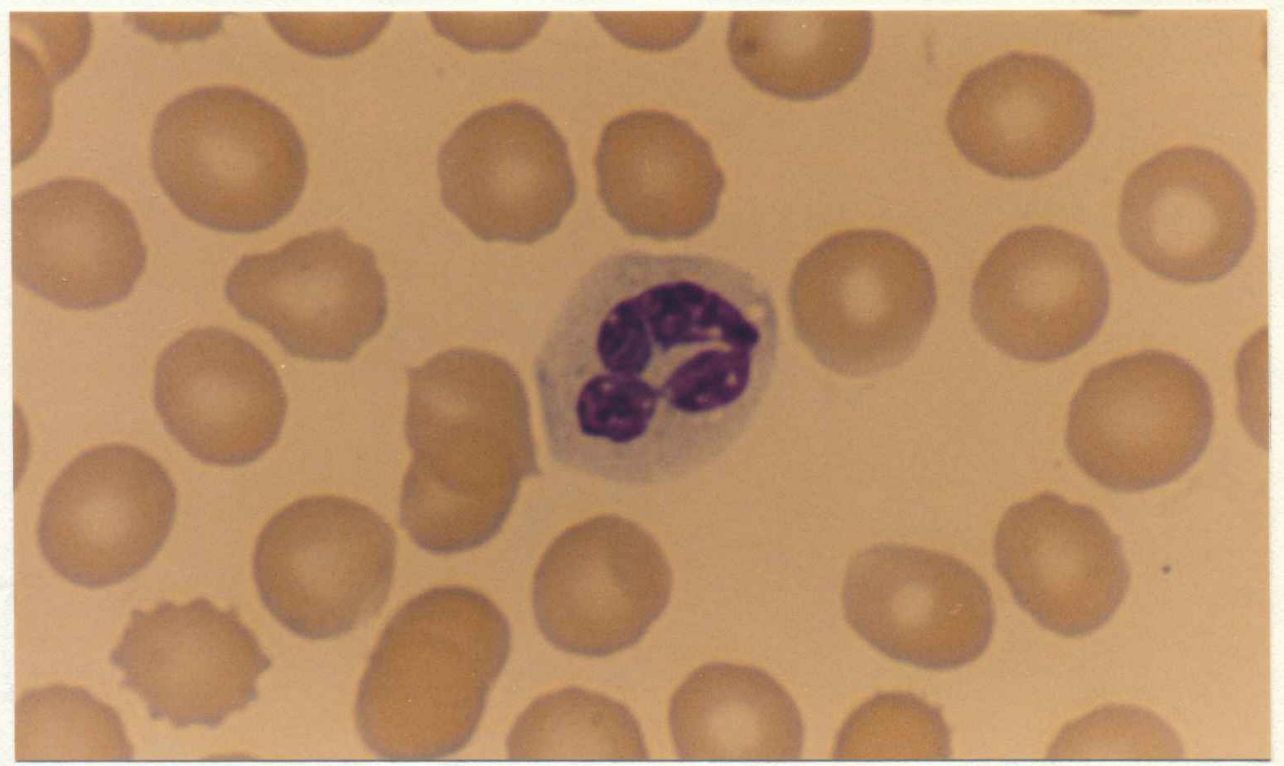

Figuree 4. Neutrophil showing slight vacuolation at 1 hour. Heparin used as anticoagulant. 1900x. 
erythrocyte crenation at 1 hour at both temperatures. Heparinized blood yielded smears with slight toxic granulation of the neutrophils at 4 hours at room temperature and at 14 hours at 40C. Sodium oxalate smears had toxic granulation at 3 hours at $24 \circ \mathrm{C}$ and at $4 \circ \mathrm{C}$. Twenty percent of the neutrophils or the 14 hour $24^{\circ} \mathrm{C}$ slide had hypersegmented nuclei and one neutrophil on the 14 hour $40 \mathrm{C}$ slide had vacuolated cytoplasm. Some of these results are summarized in Table I.

\section{TABLE I}

OCCURRENCE OF VACUOLATION IN ANTICOAGULATED BLOOD

\section{ANT I COAGULANT}

TIME AT $4 \circ \mathrm{C}$

$$
0.5123414
$$

\section{EDTA}

HEPAR IN

SODIUM CITRATE

POTASSIUM OXALATE/

SODIUM FLUORIDE

SODIUM OXALATE
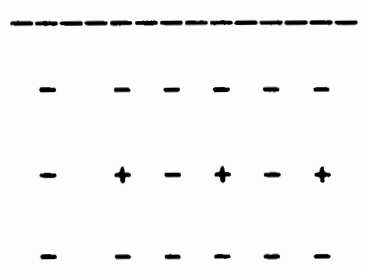

+ vacuolation of neutrophil cytoplasm observed

- vacuolation of neutrophil cytoplasm not observed

\section{DISCUSSION}

In no instance did gross morphological alterations appear prior to one hour. It is important that with the most commonly used anticoagulant, EDTA, no serious changes 
in morphology were noted prior to four hours. Vacuolation was seen only in the presence of heparin or sodium oxalate. Providing that the blood is maintained at $4 \circ \mathrm{C}$, that the anticoagulant used is EDTA or sodium citrate, and that the smears are made within four hours of the time the blood is drawn, smears made from anticoagulated blood are perfectly suitable for laboratory examination, One can be certain that vacuolation, if present, is not an artifact due to anticoagulant. 
CHAPTER II

INTRODUCTION

This second study was directed towards determining the existence of any feature common to individuals having vacuolated neutrophils. In addition, I felt that it should be possible to determine something about the developmerit of vacuolation through examination of blood smears. Specifically, one would expect to see at least equal numbers of vacuolated bands and vacuolated segmented forms if vacuolation is a maturational disturbance. If it is not a maturational disturbance, the predominant vacuolated form most likely would be the older segmented neutrophil.

\section{MATERIALS AND METHODS}

Local hospitals cooperated by watching for patients with cytoplasmic vacuolation and by providing background information and Wright's stained blood smears. I drew blood daily for ten days from four healthy volunteers. Despite the fact that some vacuolation could be attributed to heparin treatment, smears were made from both heparinized and non-anticoagulated blood. The use of heparin was necessary because blood was obtained by finger stick and only capillary tubes containing heparin were available. For comparison smears were also made by touching the finger directly to the 
slides. In addition twelve healthy volunteers were sampled by finger-stick and smears were made directly from the finger tip. All smears, heparinized and non-heparinized, were made immediately to prevent the possibility of vacuole formation caused by technique. Each peripheral smear was examined at $1000 x$ and 100 neutrophils were counted. They were scored for maturity and presence of vacuoles.

Patient information included age, sex, diagnosis, causative agent, differential white cell count, total white cell count, erythrocyte count, hemoglobin concentration, hematocrit, mean corpuscular volume, mean corpuscular hemoglobin, and mean corpuscular hemoglobin concentration. Not all information was available in all cases.

The strength of the relationship between percent vacuolation (cells exhibiting vacuolated cytoplasm per 100 cells examined) and the other variables was measured using an spss multiple regression package on portland state University's Honeywell computer.

\section{RESULTS}

One of the participating hospitals averaged 1412 monthly admissions and supplied me with an average of 2 patients per month displaying vacuolation. This amounts to only $0.14 \%$ of the entering hospital population. This number should be considered the maximum occurrence of vacuolation in the hospital population since blood smears are scanned 
not only from newly admitted patients but also from resident patients and from patients who pass through the emergency room but are not admitted.

No difference was noted between smears made from heparinized or non-heparinized blood. Three of the four healthy individuals showed no neutrophil vacuolation on any of the ten days. The fourth individual had $1 \%$ vacuolation on four of the ten days. None of the twelve one-time volunteers showed vacuolation on a peripheral smear.

The fifty-nine hospital inpatients who were selected for presence of vacuolation had a mean percent vacuolation of $17.6 \%$ isegmented neutrophils $8.1 \%$, band neutrophils 10. $1 \%$ ). As can be seen from the data in Figure 5 , the most common percent vacuolation was in the 0-5\% range.

Final diagnosig was available for forty-seven of the fifty-nine inpatients. Fifteen subjects $(32 \%)$ had septicemia, nineteen (40\%) had local infections, and thirteen (28\%) had no demonstrable infection (Table II). Nine $(19 \%$ ) of the patients with vacuolation (infected and non-infected) were known ethanol abusers. Included in this group were the only two cases of septicemia due to enteric bacteria. 
Eigure 5. Frequency of occurrerice versus percent vacuolation for hospital inpatients. 


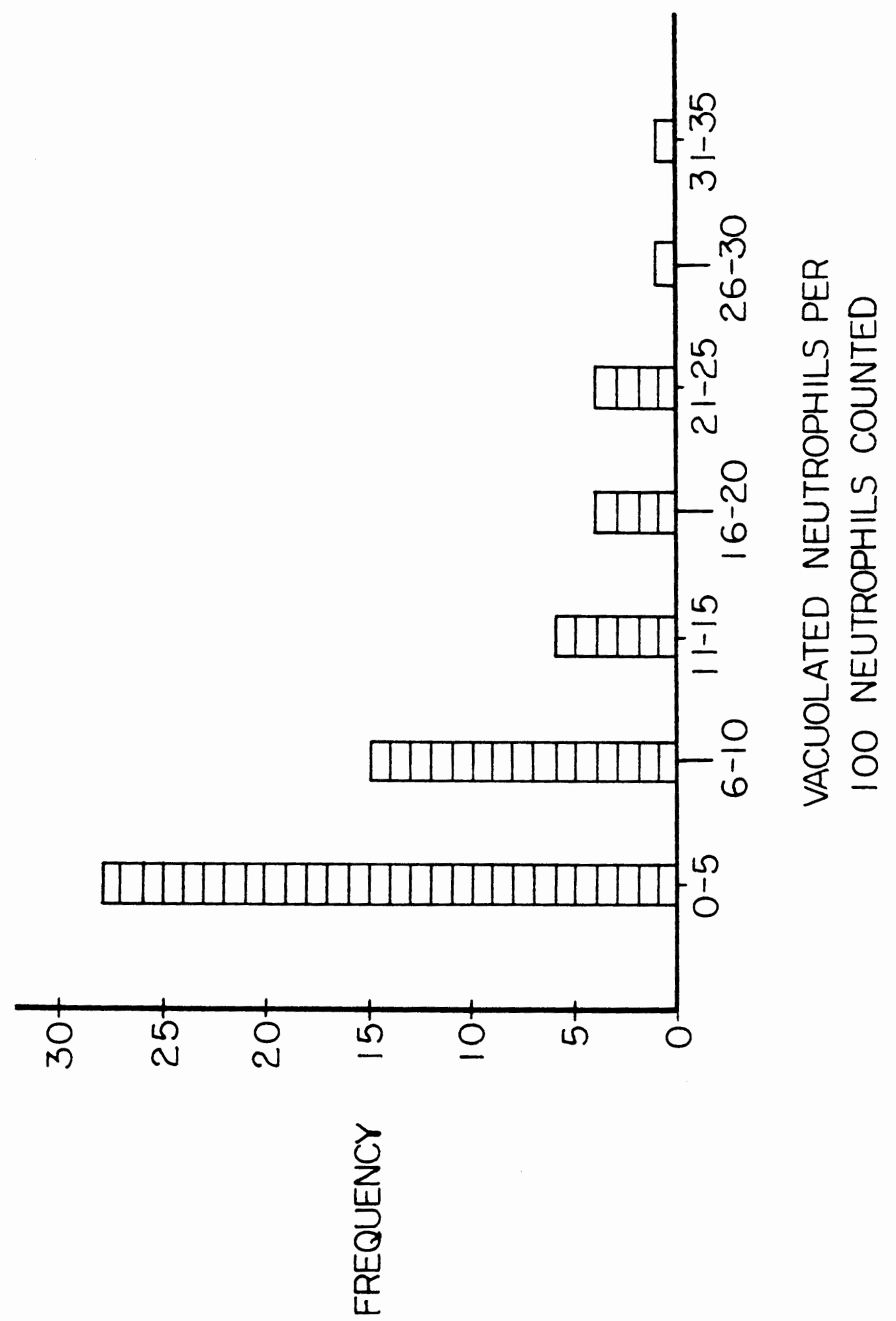


TABLE I I

DISTRIBUTION BY DIAGNOSIS, AGE, AND SEX

OF INPATIENTS DISPLAYING UACUOLATION

DIAGNOSIS

SEPTICEMIA 15 cases:

( 3 ethanol abusers)

Cause:

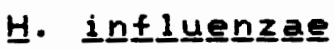

S. Rneuㅡ므므를

E. 도으노소

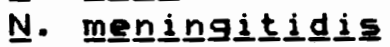

S. aㅡ므르느

Unknown

LOCAL INFECTION 19 cases: 3

( 3 ethanol abusers)

Cause:

브. iㅡㅁㅣ uㅡ므르르

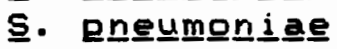

트. 드으뇨

S. auㅏㅌㅡㅗㅗ

tungi

Unknown

NO INFECTION 13 cases:

(1 ethanol abuser)

Ailment:

Lung

Heart

Stroke

Cancer

Nephritis

MALES

4

3

1

1

2

2

6

1

1

3

1

UNKNOWN 12 cases:

4

TOTAL 59 cases:

19
MEAN

AGE

22

11

2

3

4

2

3

1

66

16

52

2

2

8

3

1

3

407

63

2

1

1

2

1

8

62

46

40

52

ETHANOL ABUSERS $>$ CaSES: 3 


\section{DISCUSSION}

As noted earlier not all information was available on all patients. Access to patient records was understandably limited but this limitation did make the study more difficult and the conclusions drawn less certain. It would have been very helpful if such information as time of onset of the illness, antibiotics taken, date therapy was begun, complications, and final resolution of the illness had been available. Certainly all of this information could have been made available without compromising patient privacy. For patients currently showing cytoplasmic vacuolation smears should be made every two or three hours to track the course of the vacuolation.

Although no attempt was made to quantify the degree of vacuolation within an individual cell it was noted that vacuolation of the neutrophil cytoplasm was usually limited to a few small (1.0 micron) vacuoles. Figure 1 , from the admission blood smear of an affected individual, is typical. On occasion, vacuoles were of much greater size (Figure 6 ) or preserit in greater numbers (Figure 7 ).

Systemic and local infections taken together accounted for $72 \%$ of the patients for whom diagnosis was known. This was anticipated since activation of neutrophils by bacterial products preceeding phagocytosis is known to be a cause of cytoplasmic vacuolation (Bigley, personal communication). It is not clear what the cause of vacuolation was in the 13 


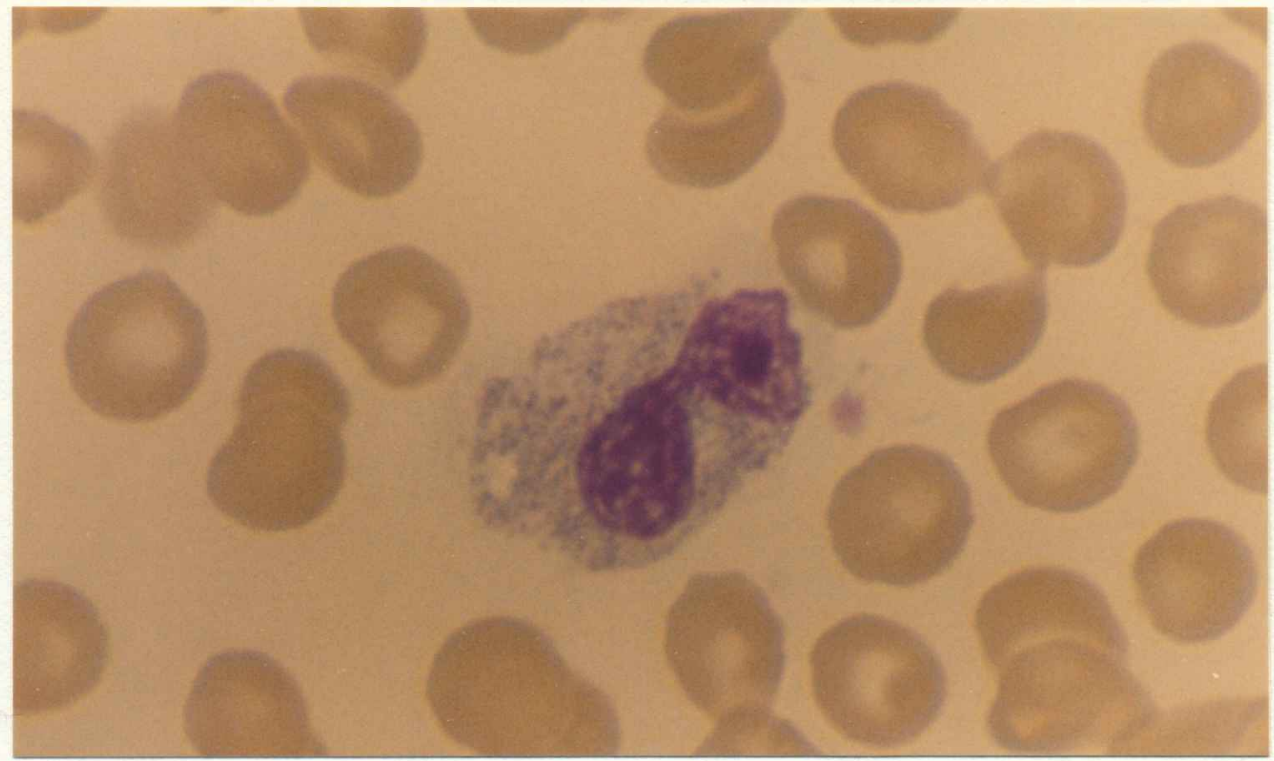

Eigurege 6. Mature neutrophil with large vacuole. $2300 \times$.

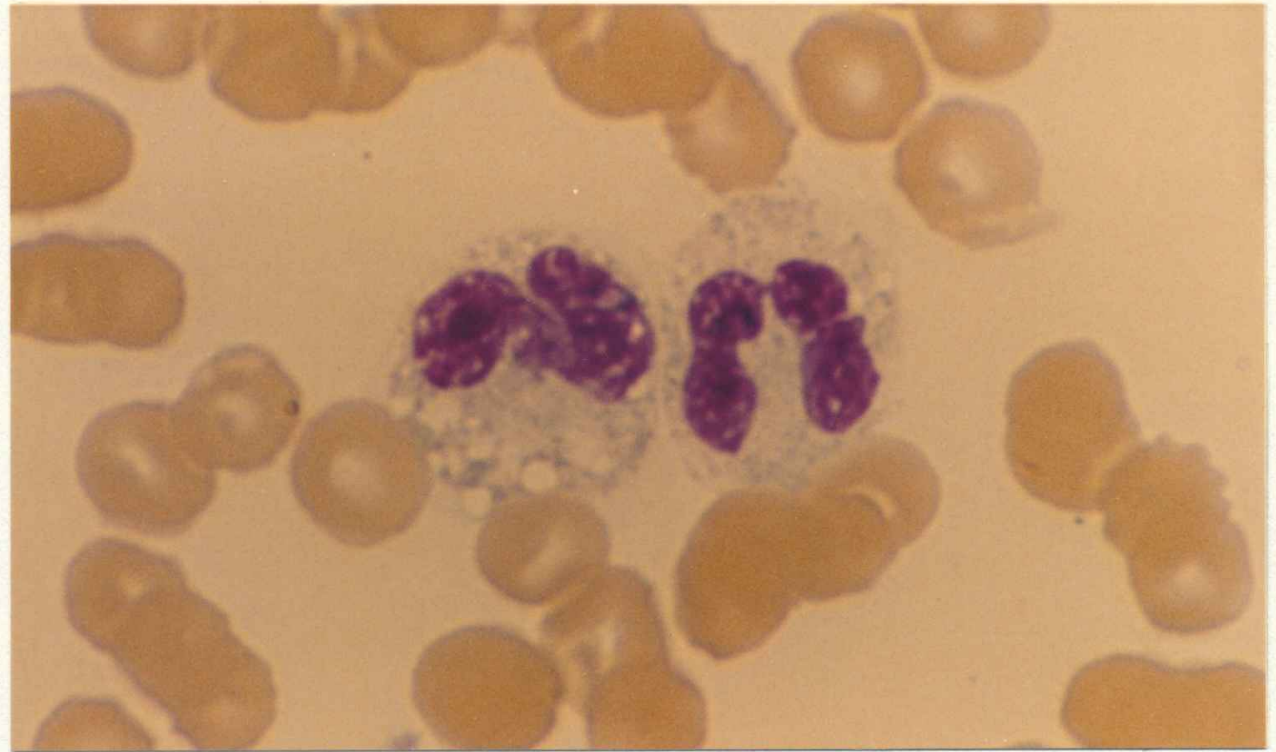

Eigure Z. Mature reutrophils with many small cytoplasmic vacuoles. 2300x. 
cases who had non-infectious diseases. There was no observable qualitative difference in the vacuolation nor was there any observable difference in persistence of vacuolation. Table III displays the sex differences noted. Twice as many female as male patients were found to have vacuolation although the percent vacuolation was very similar between sexes.

Although the hospital population does have more women (61\%) than men (39\%) most of this disparity is due to a large number of obstetrics patients, none of whom are a part of our vacuolation group. The numbers of men ard women admitted for treatment of an illness is approximately equal. TABLE I I I

SEX EFFECT OF NEUTROPHIL VACUOLATION IN INPATIENTS

SEX

$N$

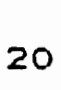

40

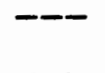

MALE

FEMALE
* VACUOLATION

ivacuolated cells

per 100 cells

examined)

N

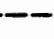

20
8.4

7.8

A large amount of information had been collected on each of the fifty-nine patients. To find out if there was any relationship between these variables and the observed percent vacuolation a multiple regression program which is part of the spss statistical package was run. Correlation 
coefficients of the independent variables with percent vacuolation are found in Table IV. A more complete list is in the Apperidix. Since percent vacuolation is not a normally distributed variable (Figure 5) the skewness of its distribution makes the observed values inaccurate estimators of the population mean (Snedecor and Cochran 1968). To correct for the skewed distribution it was necessary to perform a transformation, using the square root of the arcsine of percent vacuolation as the dependent variable in the regression (Clarkson, personal communication).

Some of the results of the regression are showr in

Table $U$. The letter $r$ stands for the regression coefficient. It is a measure of the correlation between percent vacuolation and the variable listed. The notation $r 2$ represents the proportion of the variance of percent vacuolation which is accuonted for by the listed variable. For example, $9 \%$ of the variance in percent vacuolation may be attributed to the combined variable patient age arid presence of local infection. It is important to note that the $r$ and $r=$ columns display cumulative values. Therefore, for the fifteen variables listed in the table, the cumulative coritribution is to accuont for $62 \%$ of the variance in percent vacuolation. Although thirty of the sixty-three original variables and combinations were significant at the 0.05 level, I listed only fifteen in the 
TABLE IU

CORRELATION COEFFICIENTS FOR INDEPENDENT AND CALCULATED UARIABLES

VAR I ABLE

CORRELATION

COEFFICIENT

ETHANOL ABUSE

0.22

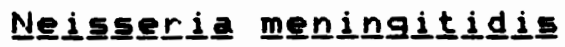

0.16

LOCAL INFECTION

0.16

SEPTICEMIA

0.11

MENINGITIS

0.11

SYSTEMIC INFECTION

0.10

SEX:

0.08

AGE

0.02

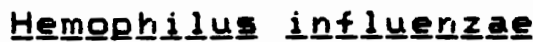

0.01

WHITE BLOOD COUNT

$-0.12$

AGE $\times$ LOCAL INFECTION

0.30

SYSTEMIC $X$ LOCAL INFECTION

$-0.19$

ETHANOL ABUSE $X$ SYSTEMIC INFECTION

0.17

AGE $\times$ WHITE BLOOD COUNT

$-0.07$

LOCAL INFECTION $\times$ 브. influeㅡㄹㅡaㅡㄹ

0.01

AGE $X$ SYSTEMIC INFECTION

$-0.16$

WHITE BLOOD COUNT $\times$ LOCAL INFECTION

0.08

WHITE COUNT $\times$ ETHANOL ABUSE

0.18

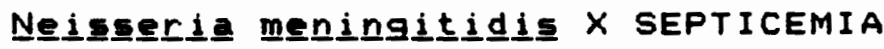

0.23

AGE $\times$ SEX

0.08

SEX $\times$ ETHANOL ABUSE

0.10

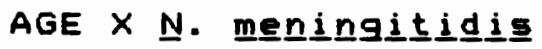

0.23 
TABLE $V$

\section{VARIABLES IN THE REGRESSION EQUATION}

VAR I ABLE

$$
\text { cum. }
$$

$r$

30

.41

$$
.17
$$

5.5

ETHANOL $X$

SYSTEMIC INFECTION

.50

.25

6.1

AGE $\times$ WBC

.55

.30

5.8

LOCAL INFECTION

.58

.33

5.3

LOCAL INFECTION $X$

H. 므니느므르트

.62

.38

5.4

AGE $\times$ SYSTEMIC

INFECTION

.65

.42

5.4

WBC $X$

LOCAL INFECTION

.67

.45

5.2

WBC $X$

ETHANOL ABUSE

$.69 \quad .48$

5.1

ETHANOL ABUSE

$.72 \quad .52$

5.1

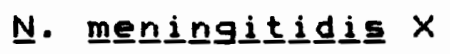

SEPTICEMIA

.74

AGE $\times$ SEX

.76

SEX $\times$ ETHANOL

ABUSE . $>7$

.78

.55

5.2

5.2

.57

.59

5.0

AGE

AGE $X$

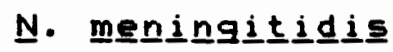

4.8

4.6 $\leq 3.15$

$\leq 2.76$

$\leq 2.53$

$\leq 2.37$

$\leq 2.25$

$\leq 2.1>$

$\leq 2.10$

$\leq 2.04$

$\leq 1.99$

RECTION REGION

FOR $F(.05)$

$\leq 4.00$$$
\leq 1.99
$$

$\leq 1.92$ 
table. The reason for this is that beyond the fifteenth step in the regression the changes seen in $r \geq$ were very small, all less than 0.01 . Fifteen variables taken together accounted for no more than $62 \%$ of the variance in percent vacuolation. In fact, if all thirty variables were included still only $70 \%$ of the variance would be explained. The fact that so many variables are involved in percent vacuolation shows that the phenomenon very likely has a number of contributing causes. Specifically, vacuolation appears to be related primarily to increasing patient age, excessive ethanol use, and presence of bacterial infection. of course the finding of an association does not prove cause. From the data it is clear that an increased probability of occurrence of vacuolation is correlated with increasing age of the patient, with increasing white blood count ispecifically neutrophils), with presence of infection, and with history of ethanol abuse. Seventy-two percent of the patients for whom diagnosis was known were known to have a concurrent infection (Table II). One could predict then, in an older patient showing vacuolation on an admission blood smear, a high probability of infection. This is especially true if there is a history of ethanol abuse.

It is worth noting that the healthy volunteer who had 1\% vacuolation on several days is both female and is over fifty years of age while the other three volunteers were all under forty. This is consistent with the age and sex fac- 
tors we have noted above. Taken together there were sixteen healthy volunteers only one of whom showed any degree of vacuolation.

The percent vacuolation on an adrission blood smear. does not correlatestrongly with either local infection (0.16) or systemic infection (0.10). However, in light of presence of vacuolation on the smear, my firidirig that $72 \%$ of these individuals are eventually confirmed as havirig an infection (32\% septicemia, $40 \%$ local infection), and the fact that ondy $0.14 \%$ of the more tran 33,000 patients eriteririg this hospital in a two year period were fourd to have vacuolation, the presence of vacuolation, regardiess of percertage, should be regarded as early presumptive evidence of a possibly dangerous infection. 


\section{INTRODUCTION}

Due in part to the difficulty of obtaining daily specimens from hospital patients and in part to the lack of control over such variables as age, sex, type of disease, antibiotics administered, and other treatments, I felt that an animal model would be helpful. Mice were chosen for ease in obtaining, bleeding, and maintaining.

There are some notable hematologic differences between mice and humans. Differential counts of human peripheral leukocytes normally show 50 to $70 \%$ segmented neutrophils (Davidson and Henry 1969). Segmented neutrophils usually represent only 8 to $15 \%$ of the circulating leukocytes in mice (Hardy 1967). According to Hardy (1967), segmented neutrophil percentages in Swiss mice have been reported to have a mean of $58 \%$.

In this study an attempt was made to induce cytoplasmic vacuolation in mice. Examination of patient histories reveal a high incidence of bacterial infection, ethanol abuse or a combination of the two in humans having cytoplasmic vacuolation. A positive relationship between the history of infection and ethanol abuse and the degree of vacuolation can be shown (chapter. II). Therefore attempts were made to induce vacuolation in mice with bacteria and 
ethanol.

MATERIALS AND METHODS

Forty swiss outbred mice itwenty females and twenty males) were obtained from Simonsen Laboratories. The mice were divided into four groups, each having five females and five males. To minimize fighting, males and females of each group were kept in separate cages. Within each cage the mice were marked with a felt pen for individual identification. Blood was drawn from al 1 mice immediately before beginning the experiment using the rapid orbital bleeding technique of Riley (1960).

All forty mice were maintained on water ad libitum and Purina Rodent chow except for the following experimental deviations: a contol group of ten received water and Rodent Chow; a second group of ten had as their only source of liquid $10 \%$ ethanol in water, a third group was injected

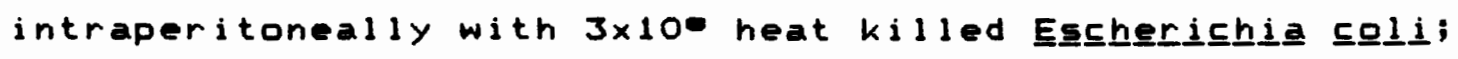
and fourth group had $10 \%$ ethanol as their only 1 iquid and were injected with E. 드요․

The bacterial suspension was prepared as follows: a loopful of E. 드욤 was introduced into $20 \mathrm{ml}$ of Luria broth and incubated at $370 \mathrm{C}$ in a shaking incubator until a klett reading of 70 was obtained $(3 \times 10$ bacteria per $\mathrm{ml})$. To ensure that the mice would survive during the experiment, the bacteria were killed by boiling the suspersion for ten 
mirites. Mccall (1969 and 1979) and Bigley (personal communication) claim that the vacuolation was due to the presence of bacterial products and not the bacteria themselves so I felt it was not necessary to expose the mice to live bacteria at this time. Aliquots of the boiled suspension were plated on nutrient agar to assure that the bacteria were killed. The remaining suspension was spun at 7000 RPM for ten minutes to sediment the cells, the broth was poured off and the cells were resuspended in $0.85 \%$ saline. The cells were washed twice more, suspended in sterile $0.85 \%$ saline and $1.0 \mathrm{ml}$ aliquots were injected into the mice in the bacteria and the bacterial ethanol groups.

All mice were bled daily for 14 days. The blood was collected in UWR micro-hematocrit capillary tubes which contained, as anticoagulant, 2.0 USP units of ammonium heparin. Although heparin has been shown to be correlated with vacuolation (Chapter I) it has only had that effect on white cells after a minimum one hour exposure at $40 \mathrm{C}$. Therefore care was taken that the blood was immediately drawn, smeared and air dried. There was neither a prolonged exposure to the heparin solution nor to reduced temperature. Blood smears were made on microscope slides, tixed for bo secorids in absolute methanol, and subsequently stained with Wright's stain in an Ames Hematek slide stainer. Slides were examined in brightfield at $1000 x$ for gross morphology. Fifty neutrophils were counted per slide and were scored for 
maturity and presence of vacuoles.

\section{RESULTS}

The initial blood smears from the mice, showed vacuolation in only three mice, two males and one female. Figure 8 shows a normal blood smear with no evidence of vacuolation. The level of vacuolation was lows 2 to 4 percent. The reactions of the bacteria, ethanol, and control group mice were very similar with mean percent vacuolations of $9.9 \%, 9.4 \%$, and $8.1 \%$ respectively. The mice exposed to ethanol and bacteria however, had a mean percent vacuolation of only 4.4\%. Although the variability withir groups is very large it is roughly the same between groups. Males had consistently higher percent vacuolation in every experimental group than did females (Figure 9 ). The difference was one of degree not of occurrence since all but one of the forty mice developed vacuolation at some time during the experiment. The mean percent vacuolation for males was approximately twice that of the females. In humans sex was a factor in occurrence of vacuolation but not in percent affected cel1s.

Concurrent with vacuolation in $42 \%$ of the occurrences was a peculiarity of the plasma which resulted in smears having a bubbly background appearance. This feature may be seen in Figure 10. The presence of this bubbly, distorted background on the slide was far more common for the male 


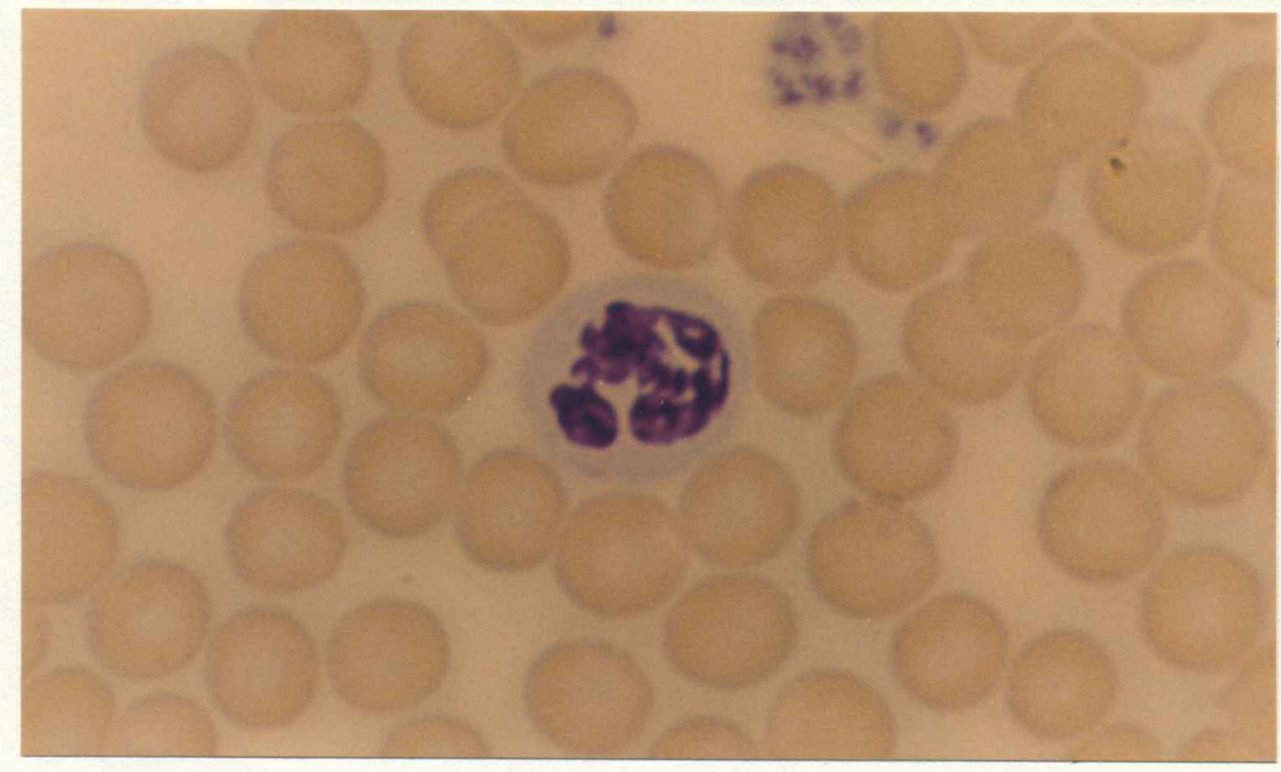

Eigure g. Normal mature neutrophil from a mouse. $2300 \times$. 
Eigure 2. Mean percent vacuolation for mice by sex and experimental group. 
崖

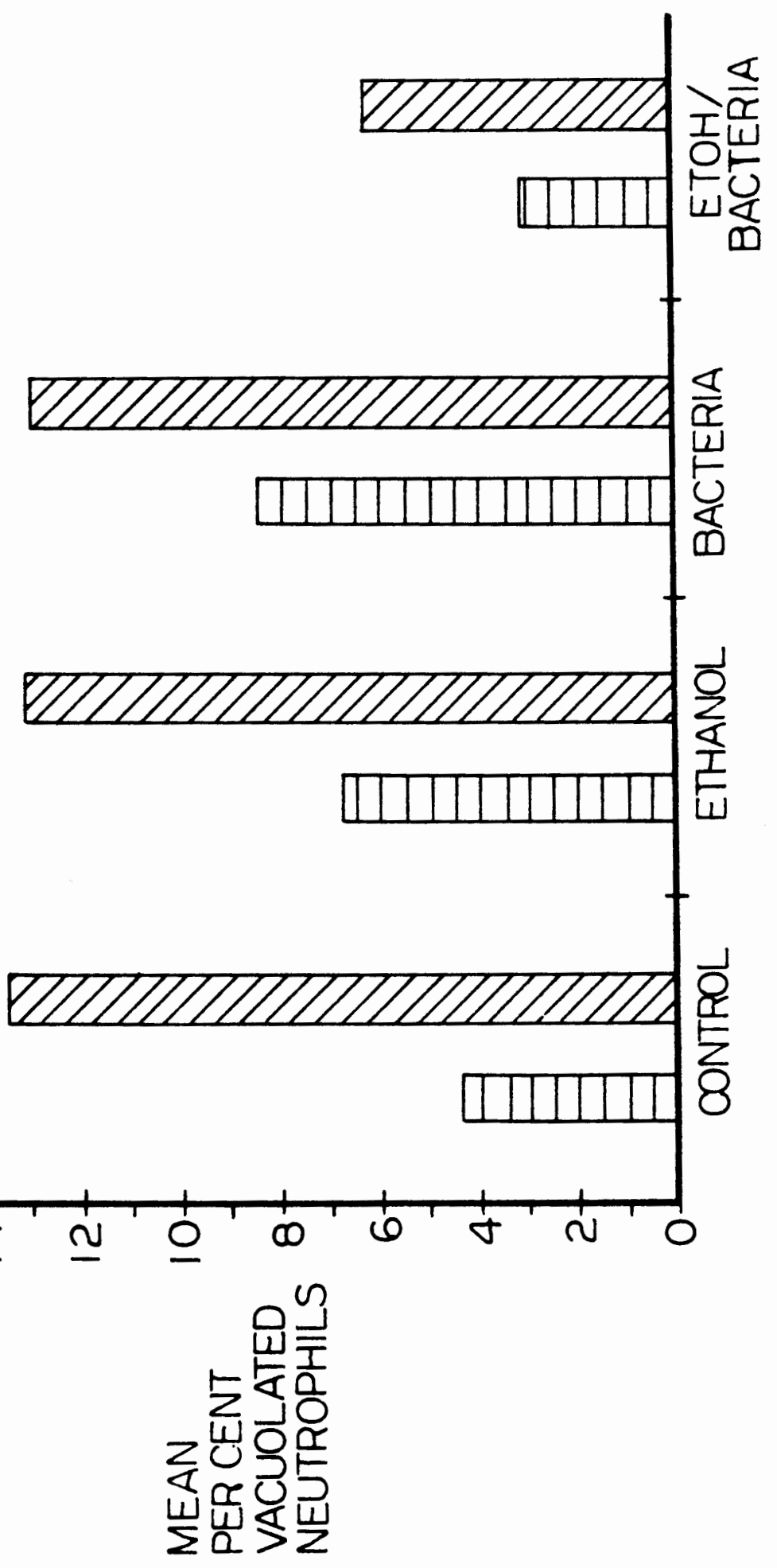




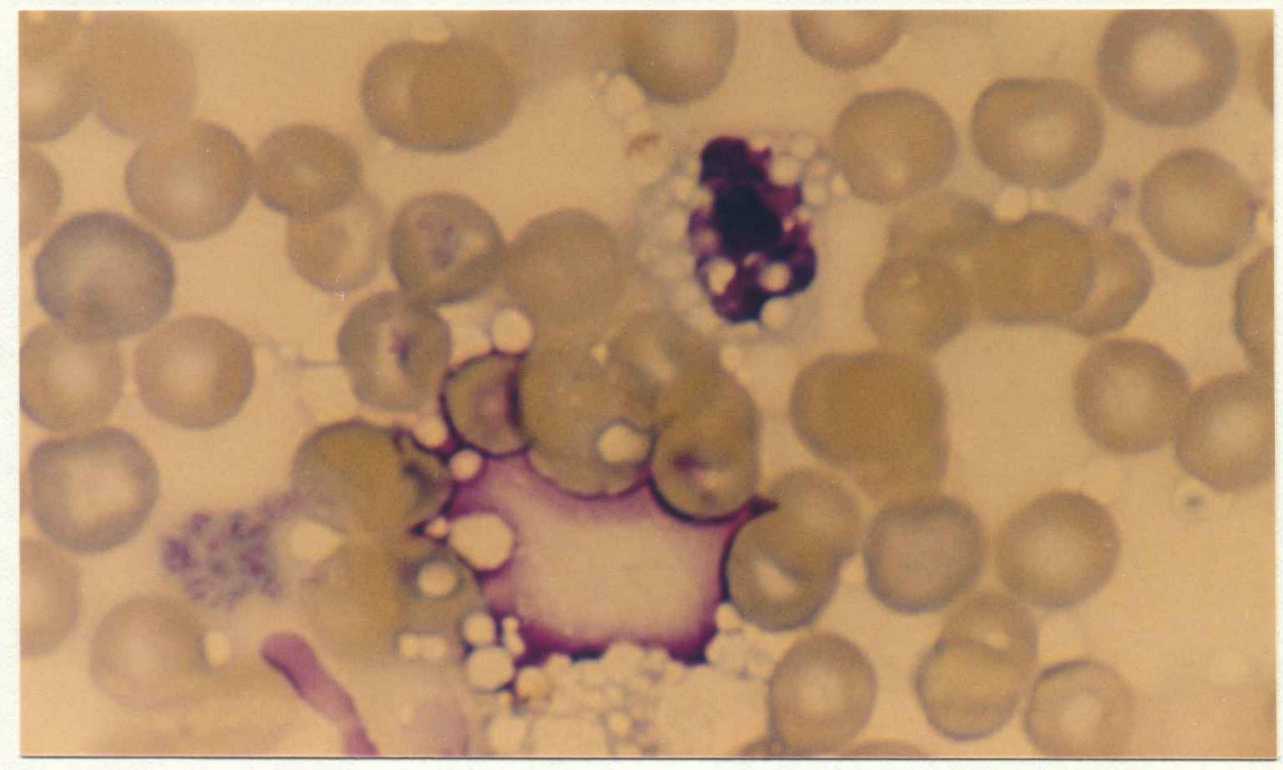

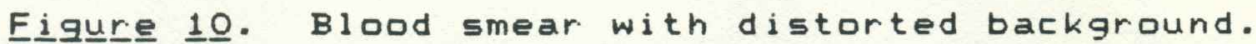
$2300 x$. 
than for the female mice (Figure 11). Comparison of Figures 9 and 11 reveal a high correlation between the disrupted background, vacuolation, and sex in mice. This phenomenon was never seen in the peripheral blood smears of humans. Those mice which had greater than $50 \%$ vacuolation frequently had neutrophils whose cytoplasm had a frothy appearance, showing such a mass of vacuoles that the nuclei were distorted (Figure 12). This feature also was never observed in blood smears from human subjects.

\section{DISCUSSION}

Since the control animals had a vacuolation response equivalent to that of the experimental groups the bacterial injections and/or ethanol feedings were evidently not the sole cause of the vacuolation. It is more likely that tissue necrosis due to daily orbital bleeding was the causative agert.

One curiosity is the lower levels of vacuolation noted in the ethanol/bacteria group. It appears as if ethanol consumption has in some way interfered with or modified the process of vacuole formation. Whether this is due to a reduction in the stress sensed by the animal, or due to a metabolic effect is not known. It is also not known why there is such a disparity between males and females in all experimental groups. Despite far higher percentages of vacuolation in males there was no difference in frequency of 
occurrence of vacuolation between sexes. Human subjects, whether male or female, had nearly the same percent vacuolation but there were differences in occurrence between the sexes, with female subjects being affected twice as trequently. 
Eigure 11. Occurrence of disrupted background by sex and experimental group. 
崖崖

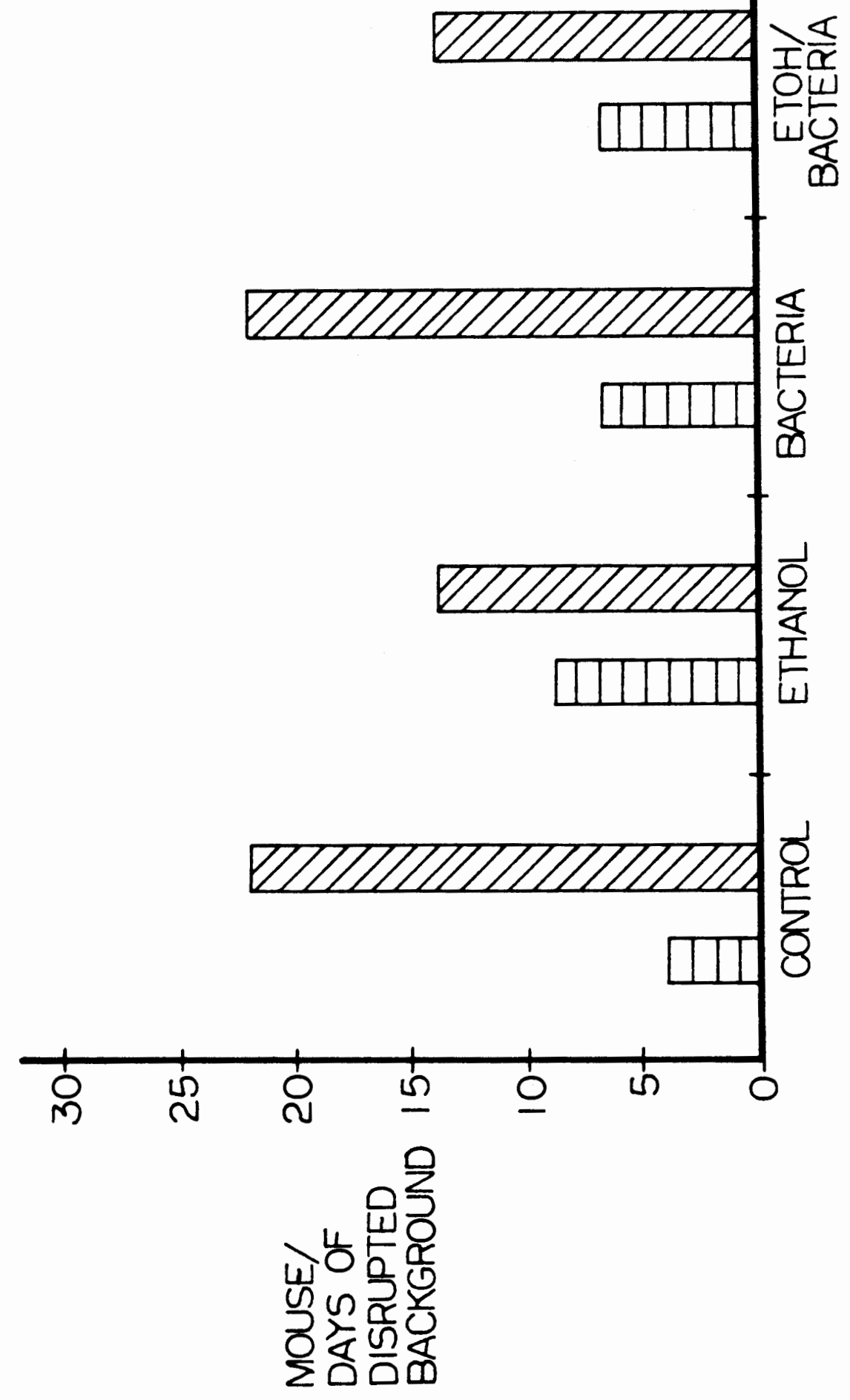




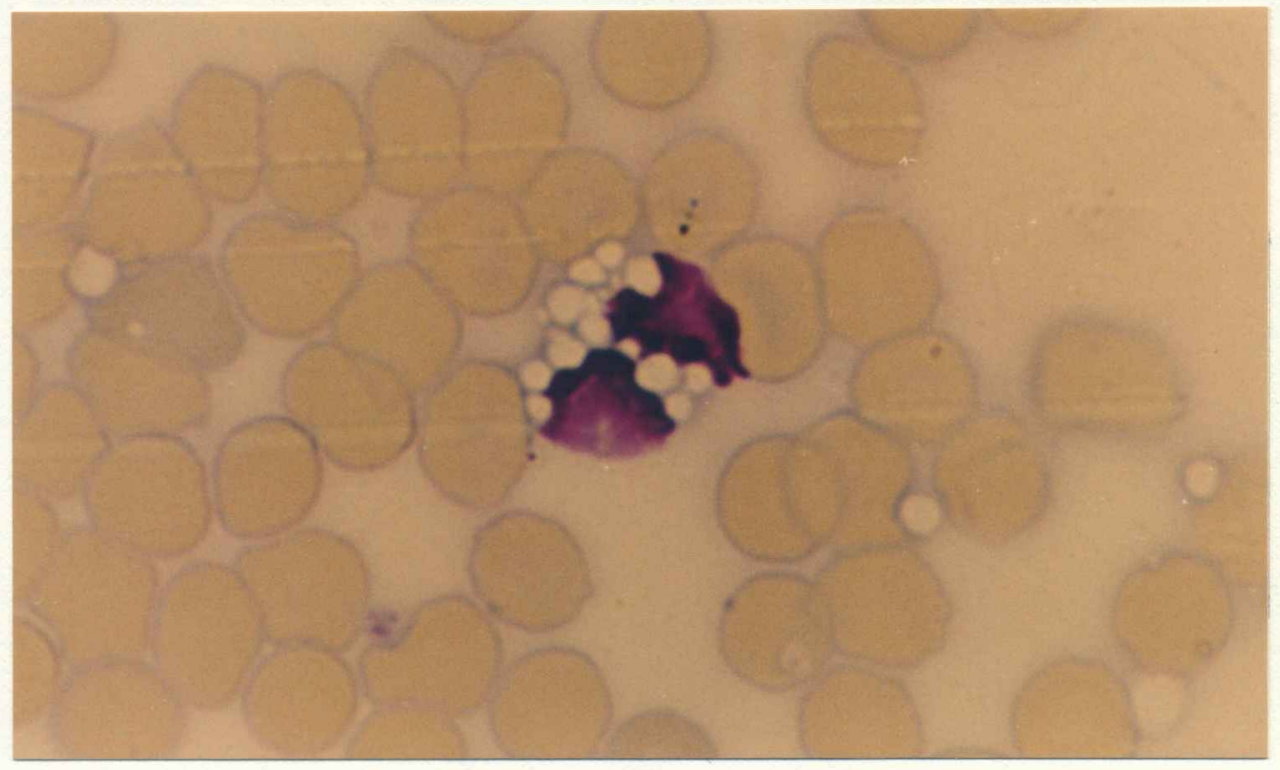

Eigures 1․ Mouse neutrophil grossly distorted by cytoplasmic vacuoles. $2300 x$. 


\section{INTRODUCTION}

Given the occurrence of vacuolated neutrophils in experimental animals it would be valuable to know whether the vacuolation ig induced by bacterial injection, ethanol ingestion, or by some other stimulus.

During phagocytosis neutrophils experience a burst of aerobic respiraton (Karnovsky 1962) coupled with an increase in hydrogen peroxide production (Karnovsky 1962). At this time nitroblue tetrazolium (NBT) can be reduced within the phagocytic vacuole to blue formazan by the action of NADH oxidase (Miller and Kaplan 1970). Nitroblue tetrazolium enters the neutrophil by precipitating with heparin or fibrinogen and being phagocytosed (Segal and Jones 1980). A low percentage of neutrophils from healthy individuals (6.6\%) (Jongeling 1975), and those from patients with nonbacterial illnesses (5.8 to 9.5\%) (Park et al 1968) give a positive reaction with NBT. Cells which have been "activated" by exposure to bacteria or their products give a positive reaction with NBT although no evidence of phagocytosis may be seen (Bigley personal communication). The percentage of positives is $29 \%$ to $47 \%$ in cases of bacterial infection (Park et al 1968) and might therefore be useful in distinguishing between cells vacuolating due to exposure to 
bacterial products and cells reacting to tissue necrosis (Bigley personal communication).

\section{MATERIALS AND METHODS}

Two runs were performed. In each run twelve swiss outbred mice were divided into four groups of three animals each. They were maintained on the same experimental regimen as the groups of mice in Chapter III, except that the E. 드뇨 used in run number one were viable, not heat killed. The reason for using viable bacteria was to see if there was a difference in the response of the mice depending on the condition of the bacteria. The bacteria used in run number two were heat killed. Peripheral blood smears were made daily for each animal and stained with giemsa IDavidson and Henry 1962). These smears were examined for presence of vacuolation. The nitroblue tetrazolium reduction test was also performed daily as outlined in Hennig (1979) with the following modifications: 1) the blood was drawn using heparinized microhematocrit capillary tubes, and 2) phorbol 12myristate 13-acetate was omitted from the procedure and an equal volume of $0.85 \% \mathrm{NaCl}$ was substituted. Slides were prepared and the cells were scored as to positive or negative NBT reaction according to the criteria of Jongeling (1975). Phorbol 12-myristate 13-acetate causes activation of the reutrophils ard was used prior to the beginning of the experiment with blood from each mouse to establish the 
maximal NBT response for the mice. The inclusion of phorbol 12-myristate 13-acetate in the original procedure was for the purpose of finding those individuals who have a deficit in bacterial killing capacity (Hennig 1979).

\section{RESULTS}

The results for runs number one and two are shown in Tables VI and VII respectively. The data listed under day one for both tables were acquired the day before the experimerital protocol was instituted. On day one of the first run three animals showed vacuolation and two had a positive NBT test. On day one in run number two, all animals were free from cytoplasmic vacuolation and all were negative for NBT reduction. However, the ability of mouse neutrophils to react to NBT was demonstrated by the strong positive reactions obtained when the cells were stimulated with phorbol 12-myristate 13-acetate (Figure 13). All mice tested with phorbol 12-myristate 13-acetate showed a positive NBT reaction.

Animals whose cells became positive for NBT reduction during the course of the experiment showed a much weaker reaction (Figure 14). Ten of twelve animals in rur number one developed a positive NBT reaction at some time during the experiment. All of the animals in run number 2 develofed a positive NBT ard for ten of them the reaction remained positive for the balance of the experiment. 
Experimental animals developed a positive NBT reaction on the average one day sooner than control animals. Vacuolation was more prevalent early in controls and later in noncontrols.

The correlation coefficient for the vacuolation/NBT relationship was only 0.23 .

TABLE VI

PRESENCE OF VACUOLATION AND POSITIUE NITROBLUE TETRAZOLIUM TESTS IN FOUR GROUPS OF MICE

RUN NUMBER ONE

\begin{tabular}{|c|c|c|c|c|c|c|c|c|c|c|c|c|}
\hline \multirow{2}{*}{\multicolumn{2}{|c|}{ DAY }} & \multirow{2}{*}{\multicolumn{3}{|c|}{ CONTROLS }} & \multirow{2}{*}{\multicolumn{2}{|c|}{ ETHANOL }} & \multirow{2}{*}{\multicolumn{3}{|c|}{$\begin{array}{c}\text { LIVE } \\
\text { BACTERIA }\end{array}$}} & \multicolumn{3}{|c|}{ ETHANOL/ } \\
\hline & & & & & & & & & & \multicolumn{3}{|c|}{ LIVE BACT. } \\
\hline & & 1 & 2 & 3 & 4 & 5 & 7 & 8 & 9 & 10 & 11 & 12 \\
\hline \multirow[t]{2}{*}{1} & VAC & - & - & + & - & - & + & + & - & - & - & - \\
\hline & NBT & - & - & + & - & - & + & - & - & - & - & - \\
\hline \multirow[t]{2}{*}{2} & VAC & - & - & + & - & - & + & + & + & - & - & - \\
\hline & NBT & - & - & + & - & - & + & + & - & - & - & - \\
\hline \multirow[t]{2}{*}{3} & UAC & - & - & - & - & - & D & + & $D$ & + & - & - \\
\hline & NBT & - & - & - & - & - & - & + & & - & - & - \\
\hline \multirow[t]{2}{*}{4} & VAC & - & + & - & + & - & + & D & & - & + & - \\
\hline & NBT & - & - & - & - & - & - & & & - & - & - \\
\hline \multirow[t]{2}{*}{5} & VAC & - & + & + & - & - & + & & & + & - & - \\
\hline & NBT & - & - & - & - & - & - & & & + & - & - \\
\hline \multirow[t]{2}{*}{6} & VAC & - & + & - & + & - & - & & & - & - & - \\
\hline & NBT & - & + & - & - & - & - & & & + & + & + \\
\hline \multirow[t]{4}{*}{7} & VAC & - & - & - & - & - & - & & & - & - & - \\
\hline & NBT & - & - & + & + & - & + & & & + & + & + \\
\hline & $+=$ & posit & ive & NBT & test & or & preserice & of & vac & $012 t$ & ion & \\
\hline & $-=$ & negat & ive & NBT & test & or & absence & of & vacu & lati & on & \\
\hline
\end{tabular}


TABLE UII

PRESENCE OF VACUOLATION AND POSITIVE NITROBLUE TETRAZOLIUM TESTS IN FOUR GROUPS OF MICE

RUN NUMBER TWO

\begin{tabular}{|c|c|c|c|c|c|c|c|c|c|c|c|c|c|}
\hline & & & & & & & & KII & LLE & & ETH & ANOL & \\
\hline & AY & $\mathrm{CO}$ & NTRC & DLS & ETH & HANC & & $B A C$ & TER : & & KILLI & ED & $A C T$. \\
\hline & & 1 & 2 & 3 & 4 & 5 & 6 & 7 & 8 & 9 & 10 & 11 & 12 \\
\hline 1 & VAC & - & - & - & - & - & - & - & - & - & - & - & - \\
\hline & NBT & - & - & - & - & - & - & - & - & - & - & - & - \\
\hline 2 & VAC & - & + & + & - & - & + & - & - & - & + & - & - \\
\hline & NBT & - & - & - & - & + & - & - & + & + & - & + & - \\
\hline 3 & VAC & - & - & - & - & - & - & - & - & - & + & + & - \\
\hline & NBT & - & - & + & + & + & + & + & + & + & + & + & + \\
\hline 4 & VAC & + & - & - & - & - & + & + & - & - & - & - & - \\
\hline & NBT & + & + & + & + & + & + & + & + & + & - & + & + \\
\hline 5 & VAC & - & + & - & - & - & - & + & - & - & + & + & - \\
\hline & NBT & + & + & + & + & - & + & + & + & + & + & + & + \\
\hline 6 & VAC & - & - & - & + & - & - & - & - & - & + & - & + \\
\hline & NBT & + & + & + & + & + & + & + & + & + & + & + & + \\
\hline & $+=$ & posit & ive & NBT & $t e s t$ & or & pr & sence & of & va & $=u 01 \mathrm{at}$ & iםn & \\
\hline
\end{tabular}

DISCUSSION

Due to the appearance of vacuoles and positive NBT reactions in control animals it is clear that the EToH arid bacteria were not the only stimuli to which these animals were reacting. The expected results were positive NBT reactions and the presence of vacuolation in experimental animals and negative NBT reactions and the absence of vacuolation in control animals. However, not only did coritrol animals have positive NBT reactiors and vacuolation 


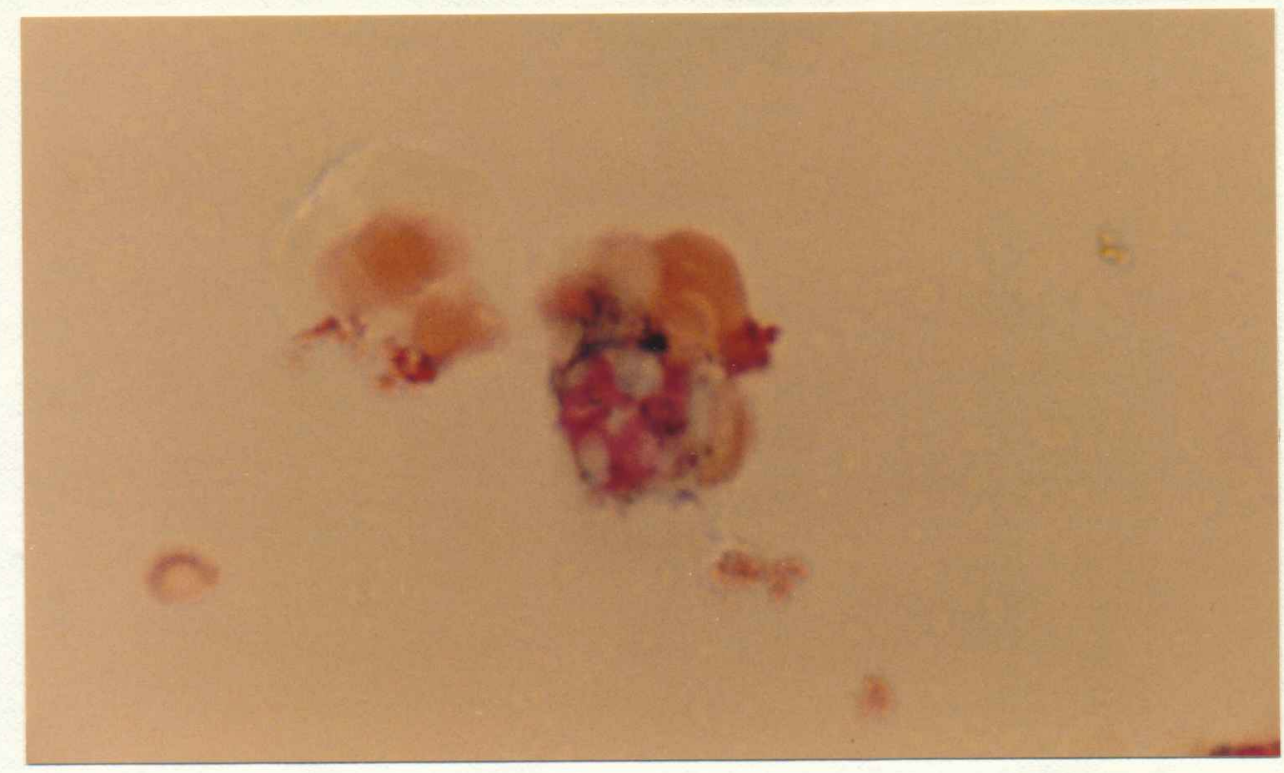

Eigure 13. Positive NBT test stimulated by phorbol 12-myristate 13-acetate. 2300x.

Eiguree 14. Positive NBT test stimulated experimental1у. $2300 x$. 
but there was little correlation between the vacuolation arid NBT resposes.

Animals exposed to viable bacteria only succumbed to their infections within three days. For this reason this discussion will be primarily concerned with the animals in run $\# 2$.

The non-control animals did respond with a positive NBT reaction on the average one day earlier and it is probable that this enhanced response is the differential amount which may be attributed to the action of the ethanol aridor bacteria. The fact that all animals ultimately responded can be attributed to the tissue irritation and destruction which is unavoidable given daily bleeding which causes tissue necrosis, encourages eye rubbing by the animals and results in local infection. There was very little difference between groups (run \#2) in number of days in which a positive NBT test result was seen (control= 10 days, ETOH= 12 days, Bacteria= 14 days, ETOH/Bacteria= 12 days).

The vacuolation response was less clear cut. The appearance of vacuolation averaged one day earlier in controls than in experimentals. Among the animals given viable bacteria only (run \#1), vacuolation appeared within the first two days.

The highest incidence of vacuolation was among the members of the ETOH/Bacteria group (run $\# 2$ ). It is in this respect that the results of the two runs are in conflict. 
The members of the ETOH/Bacteria group in run \#1 had the lowest incidence of vacuolation. On the one hand EToH seems to confer a resistance to the effects of bacterial injection, on the other hand it seems to have a synergistic effect. I believe the difference is dependent on whether or not the bacteria used are viable. The resistance effect was seen only in the case of live bacteria. This gives the impression that the growth of bacteria was inhibited in the animals receiving ETOH. It is especially interesting that the animals which received both viable bacteria and ETOH survived the entire course of the experiment with no apparent ill effects while those receiving only the bacteria died early in the experiment. In the case of animals exposed to heat killed bacteria and ETOH there was no possibility for inhibition of the bacteria and the injurious effects of the bacteria and the ETOH were summed.

The low correlation between presence of vacuolation and a positive NBT test suggests that the vacuoles seen are not phagocytic vacuoles but instead are the result of tissue necrosis due to the blood drawing technique. 


\section{CHAPTER $V$}

\section{INTRODUCTION}

Mccall et al $(1969,1979)$ believed the stimuli precipitating cytoplasmic vacuolation were circulating bacterial chemotoxins. It seems reasonable that whatever the factor is that stimulates neutrophil vacuolation it may be present in the plasma of the affected individuals, although in light of the results of chapter IV the nature of this factor is in question. As a simple test of this hypothesis I induced cytoplasmic vacuolation in normal neutrophils, in viterg, by exposure to plasma from affected individuals.

\section{MATERIALS AND METHODS}

Blood was collected in tubes containing sodium heparin from four patients displaying vacuolation. The tubes were centrifuged to sediment erythrocytes and the plasma was drawn off and frozen. Plasma was maintained at -200C until tested. Each sample was typed against types $A_{2}$ and $B$ reagent blood cells to determine $A B O$ blood group. Since in each of the four cases the individuals were type 0 , cells were obtained from a healthy volunteer (\#1) who was also type 0. Blood was collected in heparinized Vacutainer tubes as for the patients above. The type o cells were sedimented by centrifugation, the plasma was removed, the red cells arid 
buffy coat were mixed, and the cells were stored at $40 \mathrm{C}$ until used. In addition, plasma from this volunteer was frozen to use in control \#1. Control \#2 used plasma taken from a healthy voluriteer having type A blood. Plasma was chosen over serum to ensure that no factors which might be necessary to the vacuolation process were excluded.

Vacuolation of neutrophils held in wet mounts has beer reported (Gordin 1950, Bessis 1972). To minimize ary effect due to evaporation or surface contact the use of thin blood films on microscope slides was avoided.

Five $10 \mathrm{ml}$ culture tubes were used in the experiment. Each experimental tube received $0.5 \mathrm{ml}$ of cells from volunteer \#1 and $0.5 \mathrm{ml}$ of plasma from one of the patients. Control tube 1 contained cells and plasma from volunteer $\# 1$ (type 0$)$. Control tube \#2 contained cells from volunteer \#1 (type 0$)$ and serum from voluriteer $\# 2$ (type A). Smears were made immediately from each mixture, the remainder was incubated at $370 \mathrm{C}$ in a $\mathrm{CO}=$ atmosphere. Smears were made from the mixtures at interva1s of $0.5,1,2,3,4,8$, arid 16 hours, air dried, fixed in absolute methanol for one minute, stained with giemsa for twenty minutes, and finally examined at $1000 \times$ for presence of vacuales in the cytoplasm of the neutrophils.

\section{RESULTS}

Vacuolation was in evidence in the experimental groups 
early in the experiment, prior to hour 4. After that time the degree of vacuolation in the control tubes rapidly increased and ultimately equaled the vacuolation seen in the cells from most other tubes. These results are shown in Table VIII and in Figure 15.

\section{TABLE VIII}

PERCENT VACUOLATION OF NEUTROPHILS EXPOSED TO PATIENT PLASMA VERSUS TIME OF EXPOSURE

\begin{tabular}{|c|c|c|c|c|c|c|c|c|}
\hline \multicolumn{9}{|c|}{ TIME } \\
\hline PATIENT & & 0.5 & 1 & 2 & 3 & 4 & 8 & 16 \\
\hline------ & & --- & -- & -- & -- & -- & -- & -- \\
\hline$\# 1$ & & 8 & 4 & 12 & 4 & 2 & 2 & 12 \\
\hline$\# 2$ & & 18 & 16 & 14 & 14 & 8 & 10 & 20 \\
\hline$\# 3$ & & 4 & 14 & 24 & 26 & 30 & 12 & 20 \\
\hline$\# 4$ & & 6 & 2 & 10 & 4 & 14 & 0 & 50 \\
\hline CONTROL & $\# 1$ & 0 & 6 & 4 & 8 & 12 & 0 & 44 \\
\hline CONTROL & 12 & 2 & 4 & 4 & 14 & 18 & 16 & 50 \\
\hline
\end{tabular}

\section{DISCUSSION}

It appears that the cells exposed to plasma from patients known to have vacuolation of neutrophils vacuolate sooner while those exposed to normal plasma develop vacuolation at a later time. The ultimate level of vacuolation was just as high in the control tubes as in the experimental tubes, only the time frame was altered.

The differences between the experimental and control 
Eigure 15. Percent vacualation versus time for neutrophils in $\underline{\text { intero. }}$ 


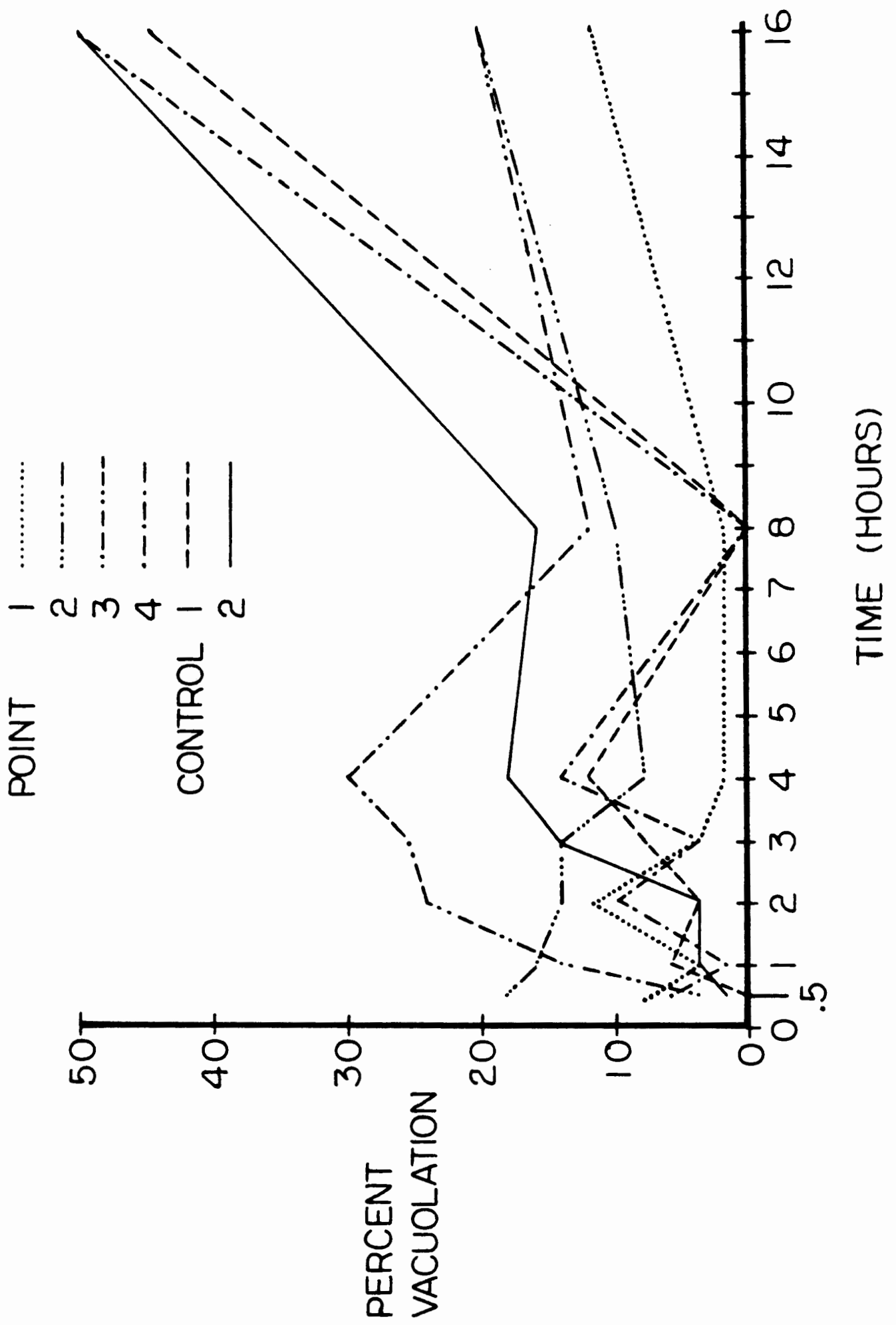


groups are given seen in Table VIII. Not until the fourth hour did the vacuolation of the controls exceed that of the experimentals. The effects of drying and surface contact must be considered when looking at the prolonged incubation times. Gordin (1952) observed vacuole development in neutrophils left in wet mounts for 6-8 hours. This causes some doubt as to the applicability of results compiled after this time. The process of vacuolation seems to be limited in the time over which it can be sustained. Those tubes which showed early vacuolation, for the most part, did not maintain that level of vacuolation and were overtaken by the tubes which showed a low initial level of vacuolation.

\section{TABLE IX}

\section{HOURLY COMFARISON OF MEAN PERCENT VACUOLATION OF EXPERIMENTALS VERSUS CONTROLS}

\begin{tabular}{|c|c|c|c|c|c|}
\hline \multirow[b]{2}{*}{0.5} & \multirow[b]{2}{*}{1} & \multirow{2}{*}{$\begin{array}{l}\text { TIME } \\
2\end{array}$} & \multicolumn{2}{|c|}{ (HOURS) } & \multirow[b]{2}{*}{8} \\
\hline & & & 3 & 4 & \\
\hline--- & -- & -- & -- & -- & -- \\
\hline
\end{tabular}

$\begin{array}{llllllll}\text { EXPERIMENTAL } & 9 & 9 & 15 & 12 & 14 & 6 & 26 \\ \text { CONTROL } & 1 & 5 & 4 & 11 & 15 & 8 & 47\end{array}$

Some differences were apparent between experimentals. For example, one of the patients with the highest initial vacuolation was diagnosed as having a severely infected wound while one of the patients with the lowest initial vacuolation had a septicemia. It is possible that the neutrophils from the septicemic patient had had a relatively long and thorough exposure to bacterial products and were 
unable to respond to the same degree as the cells from a patient having a local infection and possibly a lesser degree of exposure of neutrophils to bacterial products. However, the cells from the septicemic patient were the only ones to have as high a percent vacuolation at 16 hours as the controls.

The decrease in vacuolation seen in tubes which displayed vacuolation early could be the result of two factors: "curing" of the affected cells or death and disintegration of the affected cells. There was no apparent decrease in numbers of neutrophils present on smears with increasing time into the experiment, nor was there any observable increase in cellular debris which would lead one to think that cells were being destroyed. As a result of these observations, I believe that the transient nature of cytoplasmic vacuolation iㅡ 트므 is due not only to rapid migration of the cells out of the peripheral circulation but also due to these cells surviving the vacuolation and regaining a normal appearance.

Once again there is no clear difference between the experimentals and controls. The early vacuolation of cells in the patient tubes may be taken as an indication that there is some factor present inducing vacuolation. The delayed vacuolation of control tube 1 cannot be due only to incubation of cells and plasma from the same individual since delayed vacuolation was seen also in control tube \#2 
which had cells and plasma from different individuals and different blood groups. 


\section{FINAL DISCUSSION}

The appearance of cytoplasmic vacuolation in neutrophils in the peripheral circulation is a phenomenon which has received relatively little study. In chapter I, I was able to show that the appearance of the vacuoles, within certain limits, is not an artifact. Only on prolonged standing of the blood in the presence of anticoagulant is it possible to attribute some of the vacuolation to artifact formation.

The appearance of vacuoles on the peripheral blood smears of hospital inpatients was shown to be most strongly related to the presence of infection, particularly in female or aged patients. The value of a report of neutrophil

vacuolation as a predictor of the presence of infection is probably quite good but the overall usefulness of vacuolation as a diagnostic tool is limited by the facts that it is highly trarisient and and that it is detected in only a small fraction of patients having infection. Whether the lack of detection of vacuolation in patients having infection is due only to the short time within which it can be observed or is due to the fact that it does not invariably occur is not known.

The attempt to use mice as an animal model raised far more questions than it answered. It was possible to demonstrate the development of vacuolation in mice but the 
vacuolation had a very different appearance and probably a very different cause. Specifically, the vacuolation seen is likely to be due to tissue necrosis of the tissues around the eye caused by daily ocular bleeding. This was borre out by the NBT test which showed that there was essentially no correlation between a positive NBT test istimulation of vacuolation by presence of bacterial products) and the occurrence of vacuoles in the experimental animals. The observation that male mice had almost twice the percentage of vacuolated cells seen in females contrasted with the observation in humans that females, while having approximately the same percent vacuolated cells were twice as frequently affected. In addition, while in humans ethanol abuse was weakly correlated with vacuolation, in mice fed ethanol the occurrence of vacuolation seemed to be suppressed.

I was able to show that incubation of normal cells with the plasma from patients demonstrating vacuolation did induce vacuolation but the cause was ambiguous. Although the cells exposed to patient plasma became vacuolated first, Ultimately all samples, both experimental and control, showed vacuolation.

The occurrence of vacuolation in experimental arid control animals, of vacuolation in patients not known to have infection, the absence of vacuolation in cases of known infection, and the occurrence of vacuolation in cells exposed to normal plasma as well as plasma from affected 
patients demonstrates that the phenomenon of vacuolation of neutrophil cytoplasm does not have one simple cause.

It is possible that further study could define the biochemical nature of the factors which cause the development of vacuolation but I am not enthusiastic about the benefits that would derive from such a study. 


\section{REFERENCES}

Beard, J. and D. Knott. 1966. "Hematopoietic Response to

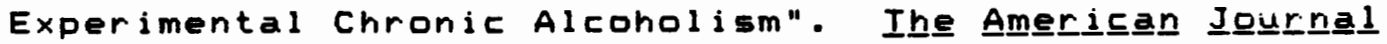

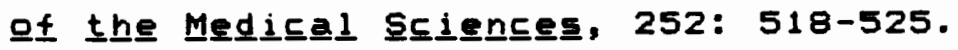

Belcour, L. and 0. Begel. 1978. "Lethal Mitochordrial

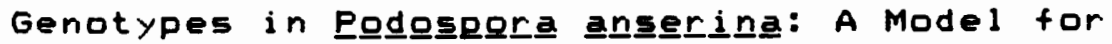

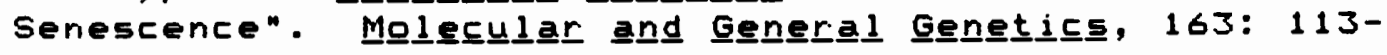
123.

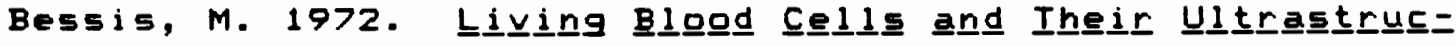
turee. Berlin: Springer-Verlag.

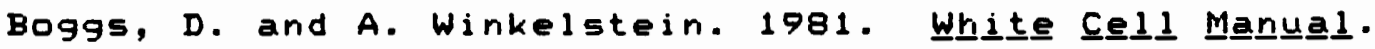
Priladelphia: F.A. Davis Compariy.

Cline, M. 1975. Inhe Whㅡㅡㅌㅡ C트료. Cambridge: Harvard University Press.

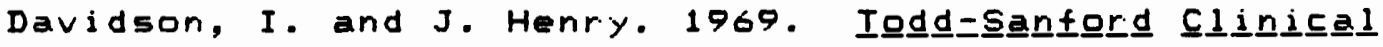

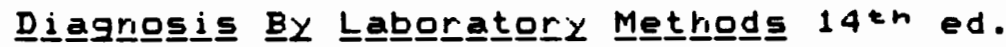

Philadelphia: W.B. Saunders Co.

Davidson, R. and J. MePhie. 1980. "Cytoplasmic Vacuolation of Peripheral Blood Cells in Acute Alcoholism".

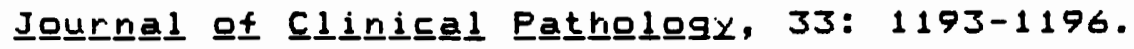

Emerson, W., P. Zieve, and J. Krevans. 1970. "Hematologic

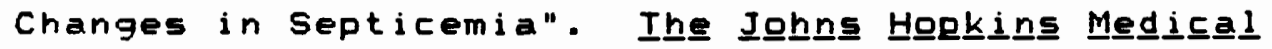
J므므므르, 126: 69-76.

Esser, K. and W. Keller. 1976. "Genes Inhibiting Senescence

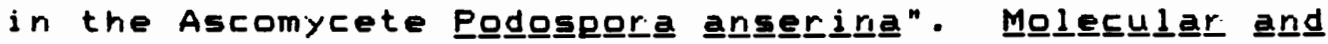

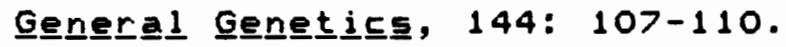

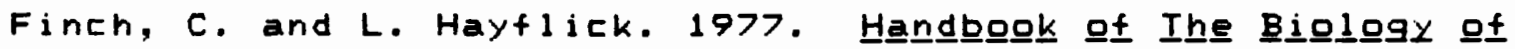
Aging. New York: Van Nostrand Reirikold Company.

Gordin, R. 1952. "Toxic Grariulation In Leukocytes Development and Relation to Cloudy Swelling". A드므 Meㅡㅁ S드르므 (Suppl 270), 143: 1-50.

Grarige, M., F. Brivet, P. Boumier and G. Tehernia. 1980. "Polynucleaires Neutrophiles Vacuoles Valeurs

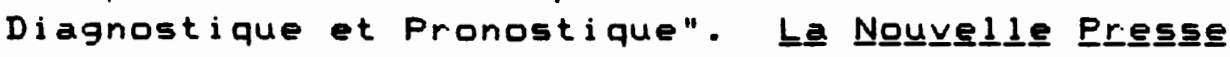
Meㅡ므드르트, 9: 2553-2554. 


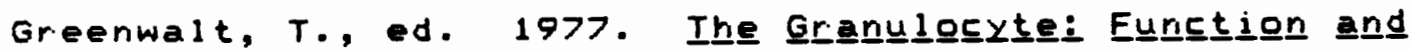

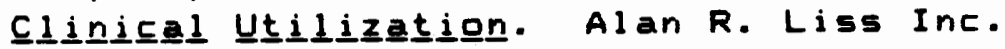

Hardy, J. 1967. "Hematology of Rats and Mice". Patholology

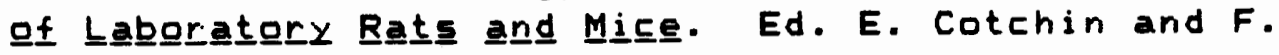
Roe. Blackwell Scientific Publications.

Hennig, C. 1979. "Nitroblue Tetrazolium Reduction Test, Hematology Division Procedure No.0550". Portland:

University of Oregon Health Sciences center, Department of Clinical Pathology.

Jacques, $Y$. and $D$. Bainton. 1978. "Changes in PH within the Phagocytic Vacuoles of Human Neutrophils and

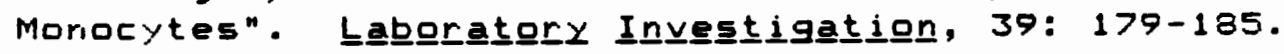

Jongeling, G. 1975. "Standardization of the Qualitative Nitroblue Tetrazolium Dye Reduction Test and Its Clinical Usefulness". Thesis. University of Oregon Medical School.

Karnovsky, M. 1962. "Metabolic Basis of Phagocytic

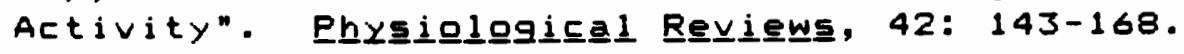

Linderibaun, J. arid C. Lieber. 1969. "Hematologic Effects of Alcohol in Man in the Absence of Nutritional

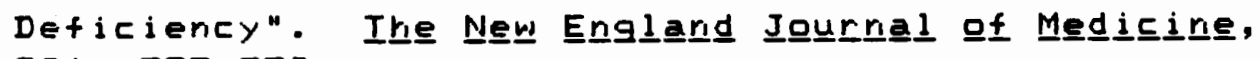
281: $333-338$.

Malcolm, I., K. Flegel, M. Katz. 1979. "Vacuolaization of the Neutrophil in Bacteremia". Archhivess of I Irtegernal Meㅡ르드르르, 139: 6>5-6>6.

MeCal1, C., D. Bass, L. Dechatelet, A. Link and M. Marr. 1979. In Vitro Responses of Humar Neutrophils to $\mathrm{N}-$ Formyl-Methionyl-Leucyl-Phenylalnine: Correlation with Effects of Acute Bacterial Infection". Igurrrial

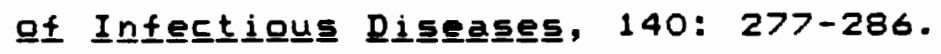

McCall, C., I. Katayama, R. Cotrar arid M. Finlarid. 1969. "Lysosomal and Ultrastructrual Changes in Human 'Toxic' Neutrophils During Bacterial Irifection".

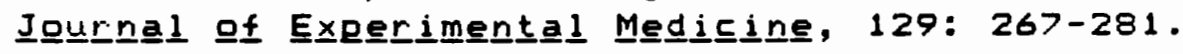

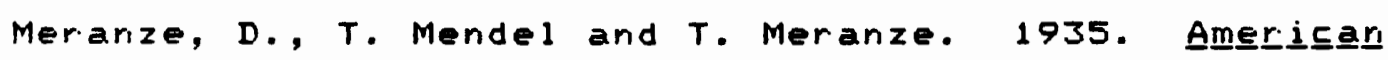

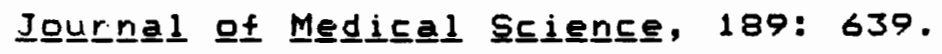

Miller, D. and H. Kaplan. 1970. "Decreased Nitroblue Tetrazolium Dye Reductior in the Phagocytes of

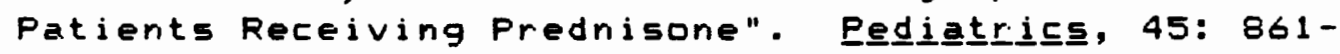
865 . 
Moxor, E., A. Smith, D. Averill and D. Smith. 1974.

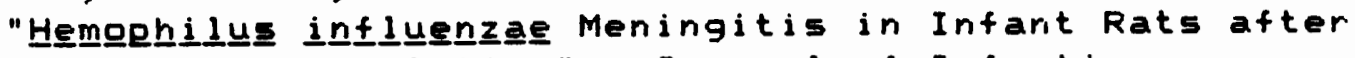

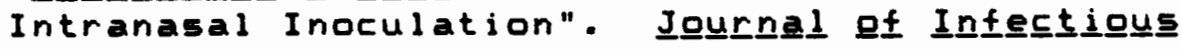
모트트르토트트, 129: 154-162.

Nathan, D., R. Baehner and D. Weaver. 1969. "Failure of Nitroblue Tetrazolium Reduction in the Phagocytic vacuoles of Leukocytes in Chronic Granulomatous

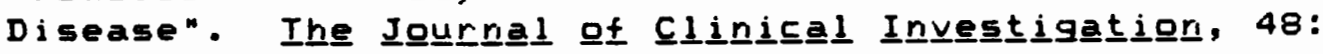
$1895-1904$.

Park, B., S. Gikrig and E. Smithwick. 1968. "Infection and Nitroblue-Tetrazolium Reduction by Neutrophils". Ihe 느크므튼, 7: 532-534.

Parmley, R., W. Crist, H. Abdelsalam, L. Boxer, A. Malluh, V. Lui and C. Darby. 1980. "Congenital

Dysgranulopoietic Neutropenia: Clinical, Serologic, Ultrastructural, and In Vitro Proliferative Characteristics". Bllgo으, 56: 465-475.

Ponder, E. and R. Ponder. 1942. "The Cytology of The Polymorphonuclear Leucocyte in Toxic Conditions". Ihe

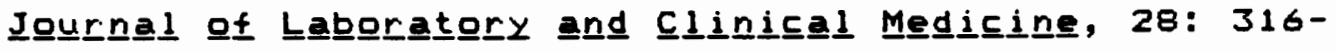
322 .

Riley, $V$. 1960. "Adaptation of Orbital Bleeding Technic to

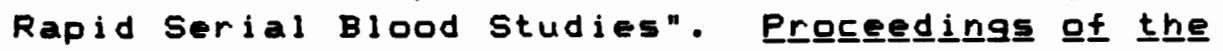

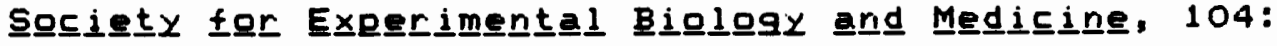
$751-754$.

Rubin, S. 1981. "Survival From Septicemia Depends On Rapid

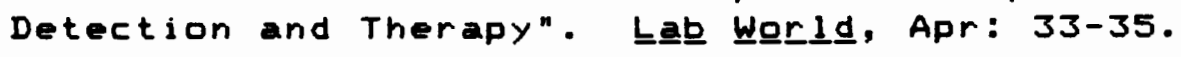

Shafer, J. 1982. "Artifactual Alterations in Phagocytes in the Blood Smear". Amerii드르 J Jou I토드므미므이, 48: 507-518.

Segal, A. and 0. Jones. 1980. "Rapid Incorporation of the Human Neutrophil Plasma Membrane Cytochrome $B$ into

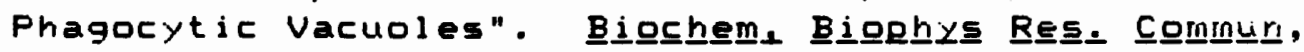
92: $710-715$.

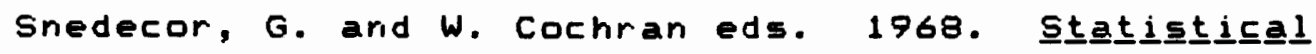
Methongds, $\sigma^{t h}$ ed., Ames, Iowa: The Iowa State University Press.

Solberg, C. and K. Hellum. 1972. "Neutrophil Granulocyte Function in Bacterial Infections". The 느므드르,

Oet: $72>->29$. 
Stiene-Martin, E. 1982a. "Reactive Morphology in Blood

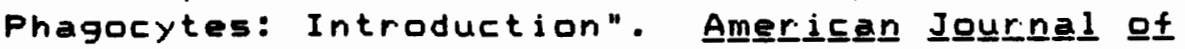
M트트트드르 I I토드므므므모y, 48: 485-490.

Stiene-Martin, E. 1982b. "An Historical Review of Toxic and Reactive Morphologic Alterations in Granulocytes

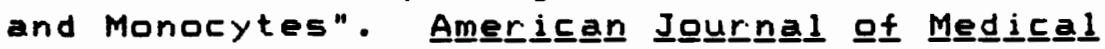
I트드므요므이, 48: 491-505.

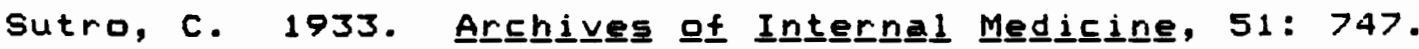
Referenced in: Gordin, R. 1952. "Toxic Granulation in Leukocytes, Development and Relation to Cloudy Swelling". A드르 M트므 S드르므 (Supp1 270), 143: 1-50.

Ward, P. 1980. "The Myeloid Leukocytoses". Ponsㅌgradㅡㅡㅡㅡㅌㅡ Meㅡ므드르트, 67(1): 219-229.

Wintrobe, M., G. Lee, D. Boggs, J. Bithell, J. Foerster, J. Athers and J. Lukens eds. 1981. Clㅡ므드르

브르르므믈, 8tned., Philadelphia: Lea and Febiger.

Zieve, P., M. Haghshenass, M. Blanks and J. Krevans. 1966.

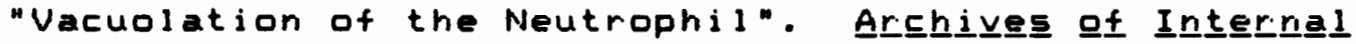
Me틈드르트, 118: 356-357. 
APPENDIX

CORRELATION COEFFICIENTS 


\section{CORRELATION COEFFICIENTS}

VAERIABELEES

VACUOLATED NEUTROPHILS (1)

ETHANOL ABUSE

SYSTEMIC INFECTION

LOCAL INFECTION

브. iㅡ피브트므르트

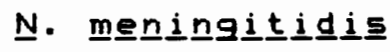

SEPT I CEMIA

MENINGITIS

AGE

SEX

WHITE BLOOD COUNT

AGE $\times$ LOCAL INF.
(1)
(2)
(3)

(4)

(5)

(6)

(7)

$\begin{array}{lllllll}.0 & .22 & .10 & .16 & .01 & .16 & .11\end{array}$

(2) $\quad .22 \quad 1.0 \quad .11 \quad .08 \quad-.12 \quad .11 \quad .15$

$\begin{array}{llllllll}\text { (3) } & .10 & .11 & 1.0 & -.04 & .41 & .42 & .92\end{array}$

(4) $\quad .16 \quad .08-.04 \quad 1.0 \quad .13 \quad-.19 \quad .01$

(5) $\quad .01-.12 \quad .41 \quad .13 \quad 1.0 \quad-.09 \quad .45$

(6) $\quad .16 \quad .11 \quad .42 \quad-.19 \quad-.09 \quad 1.0 \quad .15$

(7) $\quad \begin{array}{lllllll}.11 & .15 & .92 & .01 & .45 & .15 & 1.0\end{array}$

(8) $\begin{array}{llllllll}.11 & .08 & .48 & -.21 & .10 & .64 & .24\end{array}$

(9) $\quad .02-.02-.32 \quad .04-.34-.25-.20$

$(10)-.14 \quad .08-.04-.16 \quad .25 \quad-.07 \quad .05$

$(11)-.12 \quad .17-.11 \quad .08 \quad .06 \quad-.15-.08$

$(12) \quad .30 \quad .03 \quad-.09 \quad .83 \quad .01-.15-.05$

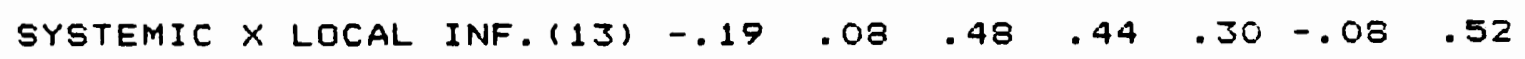

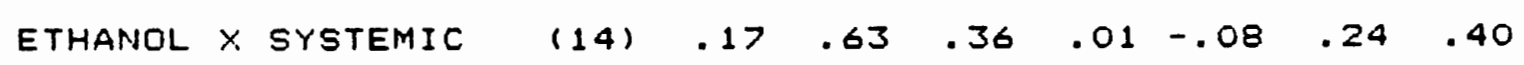

AGE $\times$ WHITE COUNT

$(15)-.07 \quad .06-.22 \quad .07-.19-.20-.15$

LOCAL INF. $x$

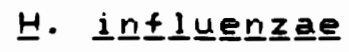

(16) $\quad .01 \quad-.08 \quad .19 \quad .34 \quad .69 \quad-.06 \quad .22$

AGE $\times$ SYSTEMIC INF.

$(17)-\begin{array}{llllllll}.16 & .14 & .73 & .03 & .16 & .16 & .79\end{array}$

WHITE COUNT $\times$ LOCAL

(18) $.08 \quad .05-.11 \quad .80 \quad .16-.15-.07$

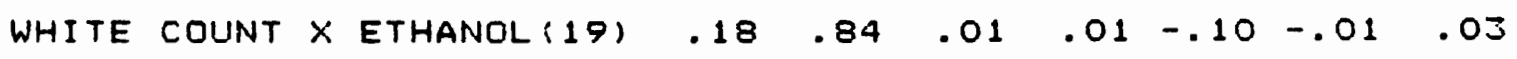

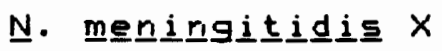

SEPTICEMIA

$\begin{array}{llllllllll}(20) & .23 & .22 & .29 & -.13 & -.06 & .69 & .32\end{array}$

AGE $X$ SEX

$(21) \quad .08 \quad .15-.20-.08-.12-.14-.16$

SEX $\times$ ETHANOL

(22) $.10 \quad .63-.15 \quad .17-.08-.06-.14$

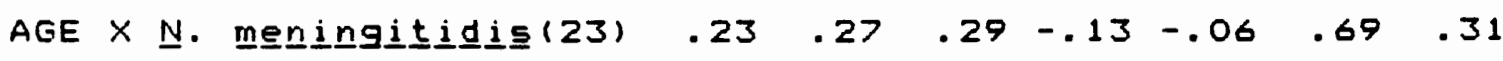


CORRELATION COEFFICIENTS (CONT.)

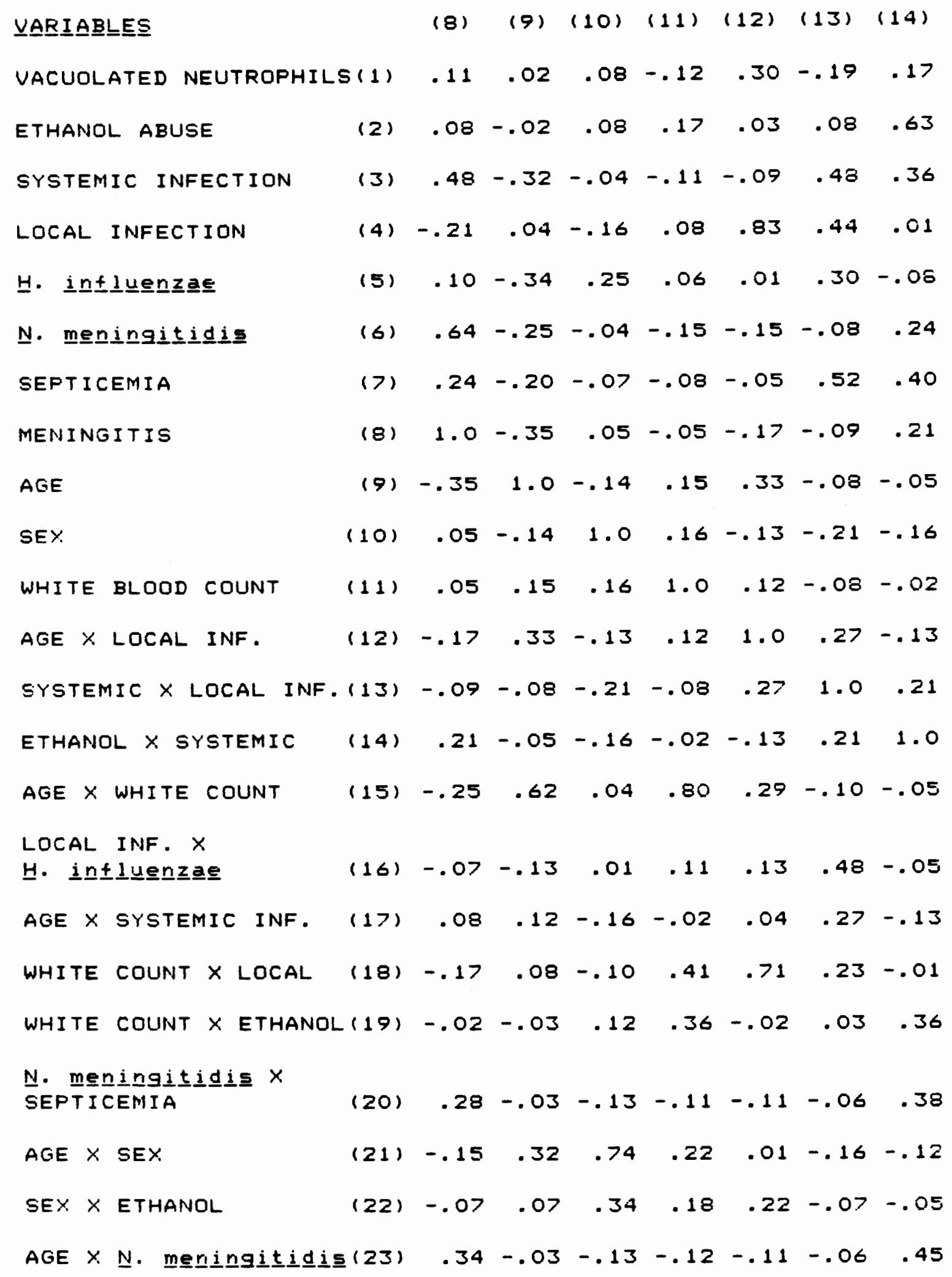


CORRELATION COEFFICIENTS (CONT.)

UARㅡ르트느토

(15) (16) (17) (18) (19) (20)

(21)

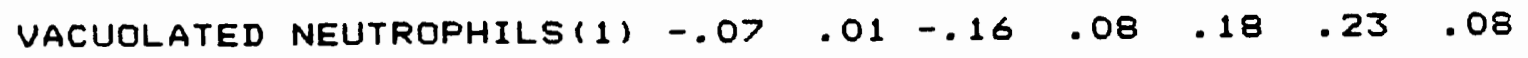

ETHANOL ABUSE

SYSTEMIC INFECTION

LOCAL INFECTION

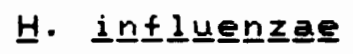

N. ․ㅡ트므므므느므므모

SEPT ICEMIA

MENINGITIS

AGE

SEX

WHITE BLDOD COUNT

AGE $\times$ LOCAL INF.
(2) $\quad \begin{array}{llllllll}.06 & -.08 & .14 & .05 & .84 & .22 & .15\end{array}$

(3) $-\begin{array}{llllllll}-.22 & .19 & .73 & -.11 & .01 & .29 & -.20\end{array}$

(4) $\quad .07 \quad .34 \quad .03 \quad .80 \quad .01 \quad-.13 \quad-.08$

(5) $-.19 \quad .69 \quad .16 \quad .16-.10-.06-.12$

(6) $-.20-.06 \quad .16-.15-.01 \quad .69-.14$

(7) $\begin{array}{llllllll}-.15 & .22 & .79 & -.07 & .03 & .32 & -.16\end{array}$

(8) $-.25-.07 \quad .08 \quad-.17-.02 \quad .28-.15$

(9) $\quad .62-.13 \quad .12 \quad .08-.03-.03 \quad .32$

$(10) \quad .04 \quad .01-.16-.10 \quad .12-.13 \quad .74$

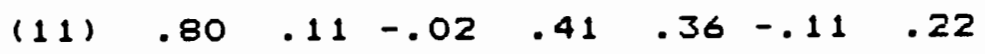

$\begin{array}{llllllllll}(12) & .29 & .13 & .04 & .71 & -.02 & -.11 & .01\end{array}$

SYSTEMIC $\times$ LOCAL INF. $(13)-.10 \quad .48 \quad .27 \quad .23 \quad .03 \quad-.06 \quad-.16$

ETHANOL X SYSTEMIC $(14)-.05-.05-.13-.01 \quad .36 \quad .38-.12$

AGE $\times$ WHITE COUNT

(15) $\quad 1.0-.06 \quad .07 \quad .34 \quad .19 \quad-.09 \quad .36$

LOCAL INF. $X$

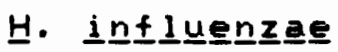

$(16)-.06 \quad 1.0 \quad .25 \quad .35 \quad-.07 \quad-.04 \quad-.12$

AGE $\times$ SYSTEMIC INF. $(1>) \quad .07 \quad .25 \quad 1.0 \quad-.05 \quad .05 \quad .30 \quad-.08$

WHITE COUNT $\times$ LOCAL (18) $\quad .34 \quad .35-.05 \quad 1.0 \quad .09-.10-.07$

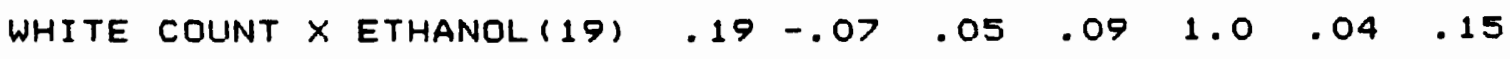

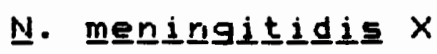

SEPTICEMIA

$(20)-.09-.04 \quad .30-.10 \quad .04 \quad 1.0-.09$

AGE $X$ SEX.

(21) $.36-.12-.08-.07 \quad .15-.09 \quad 1.0$

SEX $\times$ ETHANOL

(22) $\quad .14-.05-.11 \quad .12 \quad .63-.04 \quad .38$

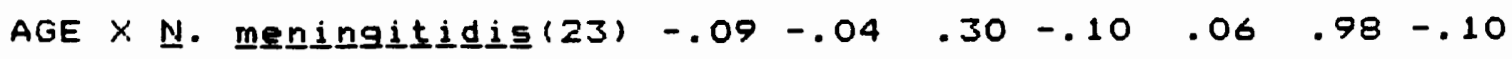


CORRELATION COEFFICIENTS (CONT.)

\section{VARIIAB느토}

VACUOLATED NEUTROPHILS(1) .10 .23

ETHANCL ABUSE

SYSTEMIC INFECTION

LOCAL INFECTION

보. innfluuㅡㅁㅡㅡㅡㄹㅡ

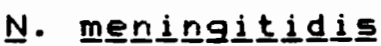

SEPT I CEMIA

MENINGITIS

AGE

SEX

WHITE BLOOD COUNT

AGE $\times$ LOCAL INF.

SYSTEMIC $\times$ LOCAL INF. $(13)-.07-.06$

ETHANOL $\times$ SYSTEMIC

$(14)-.05 \quad .45$

AGE $\times$ WHITE COUNT

(15) $.14-.09$

LOCAL INF. $X$

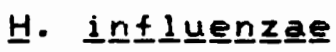

AGE $\times$ SYSTEMIC INF. $(17)-.11 .30$

WHITE COUNT $\times$ LOCAL (18) .12-.10

WHITE COUNT $\times$ ETHANOL $(19) .63 .06$

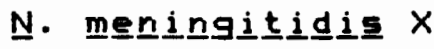

SEPT I CEMIA

$(20)-.04 \quad .98$

AGE $\times$ SEX

(21) .38-.10

SEX $\times$ ETHANOL

(22) $1.0-.04$ 